\title{
Feasibility of Integrating Other Federal Information Systems Into the Global Network of Environment \& Technology, GNET $^{\mathrm{R}}$
}

\section{Topical Report \\ May 1998}

Work Performed Under Contract No.: DE-FC21-94MC31179

For

U.S. Department of Energy Office of Fossil Energy

Federal Energy Technology Center

P.O. Box 880

Morgantown, West Virginia 26507-0880
RECEIVED

OCT 201998

OSTI

By

Global Environment \& Technology Foundation

7010 Little River Turnpike

Suite 300

Annandale, Virginia 22003 


\section{Disclaimer}

This report was prepared as an account of work sponsored by an agency of the United States Government. Neither the United States Government nor any agency thereof, nor any of their employees, makes any warranty, express or implied, or assumes any legal liability or responsibility for the accuracy, completeness, or usefulness of any information, apparatus, product, or process disclosed, or represents that its use would not infringe privately owned rights. Reference herein to any specific commercial product, process, or service by trade name, trademark, manufacturer, or otherwise does not necessarily constitute or imply its endorsement, recommendation, or favoring by the United States Government or any agency thereof. The views and opinions of authors expressed herein do not necessarily state or reflect those of the United States Government or any agency thereof. 


\section{Table of Contents}

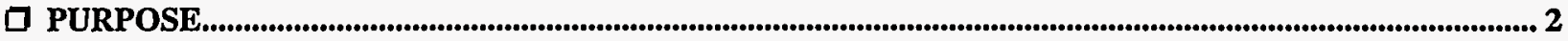

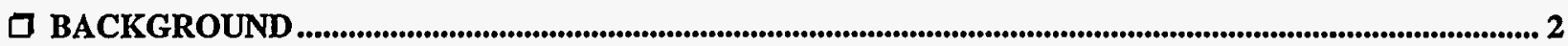

๑ OVERVIEW OF THE GLOBAL NETWORK OF ENVIRONMENT \& TECHNOLOGY, GNET®........... 2

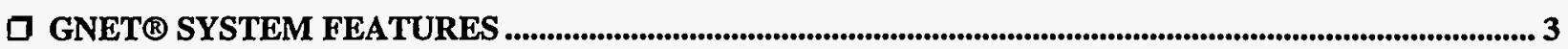

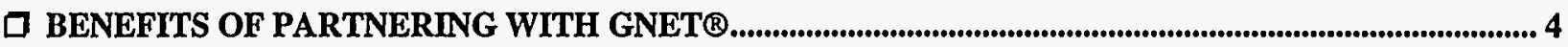

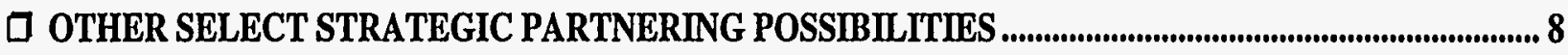

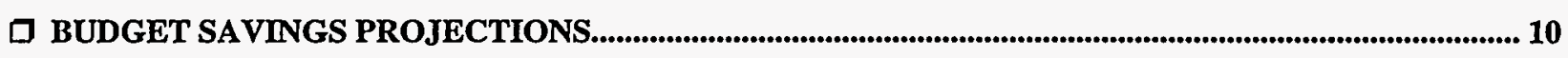

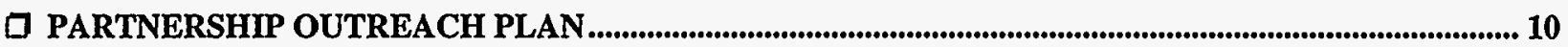

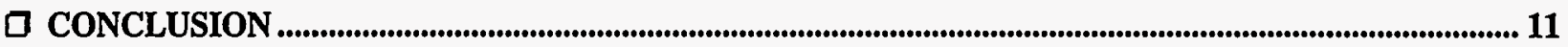

APPENDIX I - SAMPLE GNET@ PROPOSAL \& SAMPLE PARTNER LETTER

APPENDIX II - GNET® SUPPORTING MATERIALS

APPENDIX III - DRAFT SLIDE PRESENTATION 


\section{Purpose}

The Global Environment and Technology Enterprise (GETE) of the Global Environment \& Technology Foundation (GETF) has been tasked by US Department of Energy's (DOE), Federal Energy Technology Center (FETC) to assist in reducing DOE's cost for the Global Network of Environment \& Technology (GNET®). As part of this task, GETE is seeking federal partners to invest in GNET ${ }^{8}$. We are also seeking FETC's commitment to serve as GNET's federal agency champion promoting the system to potential agency partners. This report assesses the benefits of partnering with GNET ${ }^{\circledR}$ and provides recommendations for identifying and integrating other federally funded (non-DOE) environmental information management systems into GNET®.

\section{Background}

DOE's Environmental Management (EM) program is the steward of the world's largest environmental cleanup effort. In total, the program addresses hazardous and radioactive wastes and materials; excess buildings and facilities; soils, surface water, and groundwater; and associated infrastructure at 133 sites, including 10,000 individual release sites, in 31 states and 1 territory.

EM funded the creation of GETE to serve as the nexus for leveraging funds, information, strategies and methods of technology development and transfer, for the purpose of resolving environmental remediation and waste management problems throughout the DOE complex. Removing the barriers to technology deployment and commercialization is a key aspect of our mission.

GETE has defined the issues and identified the stakeholder groups that are essential to effective environmental technology commercialization. These stakeholders include federal, state and local agencies, environmental service firms, regulators, non-governmental groups, private citizens and politicians, among others. A system for linking these disparate groups was needed to promote progress and cooperation on technology issues. GNET $®$ is that system.

\section{$\square$ Overview of the Global Network of Environment \& Technology, GNET@}

GNET® is not merely a Web site. It is a practical system for managing business activities and solving problems in the environmental technology marketplace. GNET®'s system components (see figure 1) offer a suite of electronic services that speed the commercialization process and general information flow.

\section{GNET@AT A GLANCE}

- The \#1 Internet-based environmental technology system

- Over 3 million hits annually

- A hub to numerous environmental partners

- Accessed by over 160 countries

- Utilized consistently by over 400 unique US government facilities 
The network currently exchanges technology and trade-related information worldwide. GNET ${ }^{\circledR}$ contains information resources on innovative environmental technologies, government environmental technology programs, contracting opportunities, market assessments, news, current events and other material of interest to the environmental technology community. It is the only daily Internet service for the environmental technology community.

\section{$\square$ GNET@ System Features}

This network provides numerous features and capabilities to the prospective partner. It is not to be confused with simple Internet systems services offering. GETF as the system operator will seek partners that can benefit from the existing resources and does not intend to create new systems. It has "plug and play" system components that can be customized to the specific organizations' needs. A simple illustration of the system is found in Figure 1.

\section{Figure 1: GNET@ System Features}

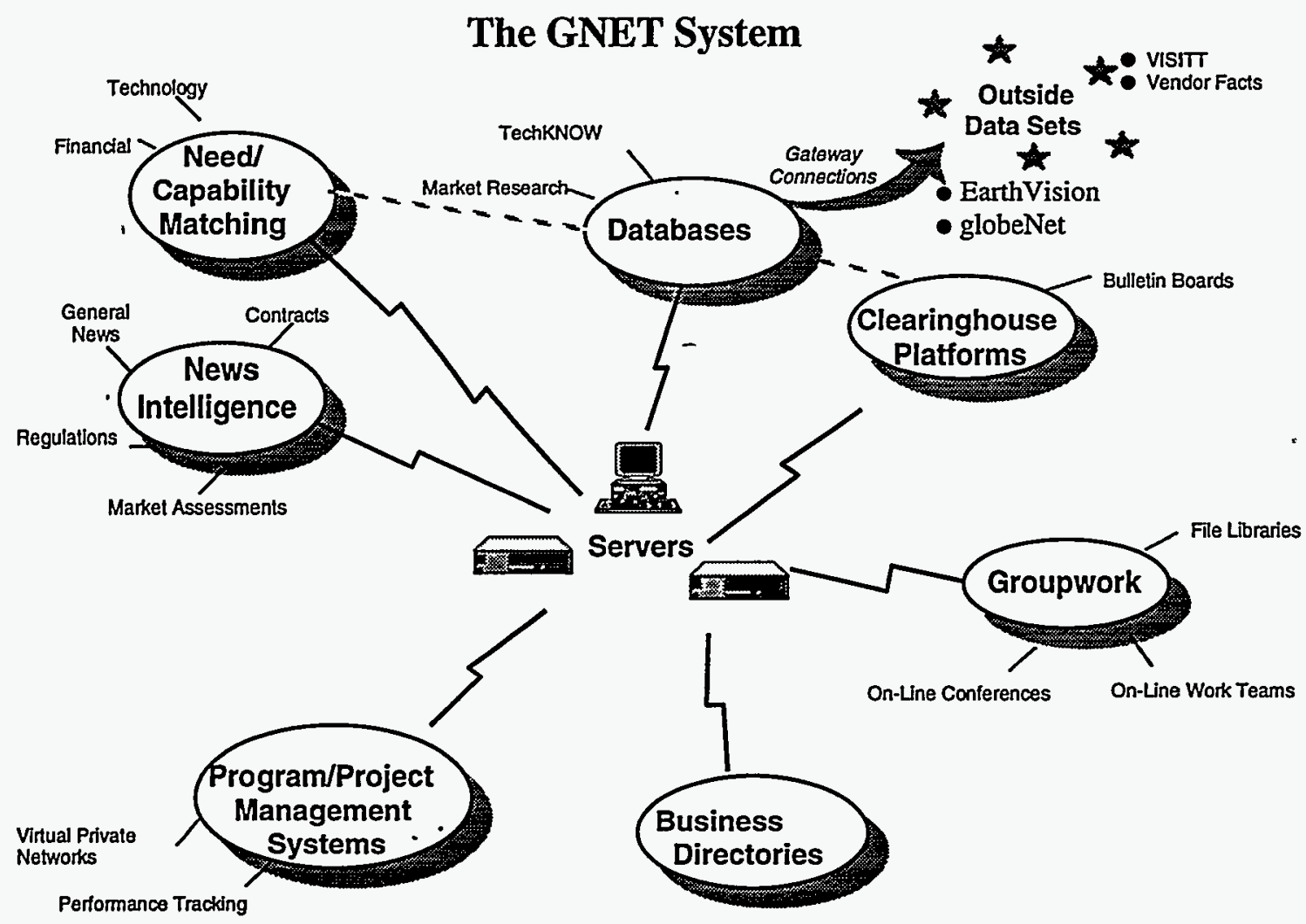


$>$ News / Intelligence: News is one of GNET@'s largest audience draws. GNET® provides timely news feeds on a variety of topics culled from a variety of news sources. News is abstracted by GNET®'s experienced editorial team and published on the site daily for free. All news is tagged to keywords so that customized news feeds can be created for partners.

$>$ Groupwork: GNET ${ }^{\circledR}$ offers Virtual Private Networks (e.g., Intranets, Extranets) that promotes successful groupwork. These secure workspaces allow for chat style meetings, bulletin boards, custom news feeds, directories, file libraries and more.

$>$ Databases: GNET $\circledast$ offers public and private, keyword-searchable databases on a wide variety of subjects and provides access to other existing databases and on-line resources. GNET®'s TechKnow database, for example, provides a forum for environmental technology businesses to market their products and services. TechKnow currently contains information on over 1,000 technologies being marketing by numerous American companies. TechKnow's interactive, two-way design allows firms to update their progress in real-time fashion.

$>$ Clearinghouse Platforms: Information exchange with text and file transfer is made possible through message board systems

$>$ Who's-who Business Directories: GNET® offers the ability to look-up user addresses based on one or more criteria, including name, organization, geography, keyword, etc.

\section{Benefits of Partnering with GNET®}

Leveraging GNET $®$ capabilities with resources and expertise from other federal agencies, programs, and organizations is a necessary step to keep the system robust. New partnerships will bring additional "critical mass" to GNET®, helping other agencies and programs fulfill their missions while reducing DOE's mortgages on the GNET® system. The benefits of GNET® to federal partners include:

\section{What GNET@ Offers Our Partners:}

Cost effective tools and content

Immediate affiliation with the most prominent environmental technology information network.

Access to turnkey services and an audience generating millions of hits per year that provides immediate outreach support their program goals.

A proven approach for building networks to support national policy goals.

A successful track record of partnerships.

Accelerated "time to market" for your program, project and information. 
GNET@ offers partners the system for environmental technology information.

GNET® has proven its effectiveness to supplement face-to-face exchange of information and provide a management platform for coordinating work. The system has been a hallmark of our information exchange and outreach program. GNET® provided GETE with essential, early credibility by supplying reliable news, information and solutions for environmental problemholders. Vice President Gore, for example, has promoted GNET® as the network for federal interagency environmental technology collaboration and information-sharing activities. Site quality, effective outreach, advertising and the support and involvement of credible GNET ${ }^{\circledR}$ partners, such as the Environmental Protection Agency, has driven the popularity of the system. The system's reputation and ability to deliver effective results have made it the network of choice for a number organizations. Some examples of this include:

$>$ President Clinton's Technology For Sustainable Future Initiative - For this national initiative, GNET ${ }^{\circledR}$ was the catalyst for collaborative group work activities and information sharing among the private sector, local and state governments, national laboratories, public institutions and industry. TSF was a national campaign to develop U.S. environmental technology policy and gain inputs on viable environmental technologies. The major goal of the initiative was to develop a National Environmental Technology Strategy. This strategy has strengthened the U.S. environmental technology industry and promoted the development and commercialization of new advanced environmental technologies for more effective pollution cleanup, monitoring, and prevention.

$>$ Rapid Commercialization Initiative - GNET® developed a virtual private network for this partnership between technology demonstrators, federal agencies and states. The network provides a secure "work space" for the effective management of this partnership's activities prior to formal report publication.

$>$ The Interstate Technology \& Regulatory Cooperation Working Group - GNET® developed a virtual private network for this partnership between technology demonstrators, federal agencies and states. The network provides a secure "work space" for the effective management of this partnership's activities prior to formal report publication. This network used the public GNET ${ }^{\circledR}$ system to solicit comment from the community on draft standards and documents.

$>$ Environmental Technology Initiative - For the U.S. Environmental Protection Agency, GNET® developed an interactive tracking system and outreach vehicle for its environmental technology projects throughout the world. The system leveraged the GNET ${ }^{\circledR}$ audience in an effort to ensure investments were made available to the public

$>$ World Engineering Network - For the National Science Foundation, GNET® assisted in the development of the World Engineering Network (WEnet). WEnet encourages partnerships, and promotes information sharing among the world's engineering community. The system incorporated several GNET $®$ components. 
Agencies can feel comfortable that they will not be the first organization to leverage the power of GNET®.

GNET@ can provide immediate turnkey services and an interested audience.

GNET partners will benefit from GNET's experience developing GNET. This experience allows us to provide our partners with "turnkey services" that add immediate relevancy and substance to their programs and projects. From market studies to daily news feeds, GNET $®$ offers a variety of comprehensive and timely resources for the environmental technology marketplace. Backing up the electronic system is a "human network" of seasoned environment and technology professionals to provide technical assistance, partnering advice and other helpful information. Environmental databases can be incorporated with ease into the GNET® system.

Becoming a GNET $®$ partner allows agencies to associate with GNET $®$ 's quality content including up-to-date news, procurements, and contracts in private sector, government, and technology development markets. Our annual "hit rate" - an indication of site visitation - is $3,000,000$. Our partners are immediately exposed to this large audience providing them with instant visibility their programs and projects. GNET®'s audience is based around the world, with almost 51 percent coming from small businesses, and annual growth has exceeded 100 percent.

An added reason for partnering with an established system is benefiting from the outreach and promotion conducted regularly by GNET $®$. GNET $®$ regularly advertises on the Internet through the keyword "environmental" on the Lycos search engine and via other mediums. The GNET $®$ team demonstrates the system to thousands of stakeholders per year through regular participation in conferences and other demonstrations around the country. These events are often made possible through donations from partner organizations.

A proven approach to partnering and building networks to support national policy goals.

We developed a systematic strategy for providing partners with the service that will help them succeed. Through the power and flexibility of the GNET ${ }^{\circledR}$ system, GNET $®$ can create a subsystem where partners can integrate their system without losing their identify or independence. They can also gain access to GNET's customized data. The process by which GNET@ markets to potential partners is as follows:

- Target programs that overlap with GNET®'s mission.

- Of those applicable programs, develop intelligence necessary to determine programs that can capitalize on GNET®'s strengths

- Demonstrate GNET@'s capabilities

- Demonstrate the benefits of leveraging for GNET® and the potential partner

- Define and focus scope of work

- Implement the partnership 
An excellent example of this is the globeNet ${ }^{\mathrm{TM}}$ system created by GETF with GNET ${ }^{\circledR}$ components. globeNet ${ }^{\mathrm{TM}}$ is a system that supports the creation of international environmental management standards. GETF has been integrally involved with the development of a series of voluntary environmental standards and guidelines developed by the International Standards Organization (ISO). ISO 14000 is designed to help businesses incorporate sound environmental management systems and processes into existing systems and practices. ISO 14000 is intended to ensure that companies are proactive, rather than reactive, in their strategies to address the potential environment impacts of business practices. ISO 14000 is intended to enhance American competitiveness and technology internationally, promote partnership between government, industry, and communities, foster regulatory reform, and improve pollution prevention capabilities. The American National Standards Institute in cooperation with GETF partnered with GNET® to launch globeNet ${ }^{\mathrm{TM}}$. Since its launch in February 1997, the site has been recognized as the leading information site on ISO 14000. This audience will begin to need information on technologies and be directed to TechKnow. The leveraging and benefits for each partner are full circle.

\section{GNET@ 's partnering successes are growing daily.}

GNET® has extensive experience in identifying partners crucial to project success. These partnerships continue to grow as GNET@'s network and reputation develops. A federal agency "champion" to assist with promoting the site will undoubtedly bring even more partners. It is our expectation that FETC will serve in this capacity. Recent partnership developments include:

- GETE has recently completed a Memorandum of Understanding with the International Environmental Technology Center (IETC). This center is part of the United Nations Environmental Programme (UNEP). This agreement is a non-financial transaction in which GETE will agree to trade environmental technology databases with UNEP. This trade has occurred and UNEP technologies are currently on the TechKnow database. UNEP is in the process of publishing the technologies listed in TechKnow on CD-ROM and in print to distribute to third world countries that have limited or no Internet access.

- We are working with numerous groups at the EPA under various agreement formats to facilitate interagency cooperation by creating an exchange location for Brownfields technical data and to create a CFC management component to TechKnow.

- We are working under an agreement with the Department of Labor to assist in the management of the EnviroJobs program which facilitates the retraining of displaced workers for $21^{\text {st }}$ century Environmental Management System positions. Additionally, we are involved in discussions with personnel in the EPA Superfund office to create community involvement and jobs training workspaces for 9 target communities affected by Superfund site activities. A VPN and Web site has been created for this project. 
- Following preliminary meetings, GETF received a letter of interest from The United States Agency for International Development (USAID) for a project that involving collaboration with the Federation of Indian Chambers of Commerce and Industry (FICCI) to implement an initiative to share US Environmental technology information with the Indian Government and Indian Business.

- We are also involved in discussions with the Department of Defense and various other parties concerning the formation of an agreement to join or share resources with DENIX. This partnership would significantly expand the scope of the information that is available to both organizations.

\section{$\square$ Other Select Strategic Partnering Possibilities}

Table 1 illustrates potential GNET® strategic partnering opportunities and their status.

\section{Table 1: Select GNET@ Federal Partner Targets}

\begin{tabular}{|c|c|c|}
\hline GNET@ Partner Target & Opportunity Description & Status \\
\hline $\begin{array}{l}\text { U.S. Department of Commerce } \\
\text { Environmental Business Council initiative }\end{array}$ & $\begin{array}{l}\text { The Environmental Business Council is } \\
\text { seeking to incorporate all state councils into } \\
\text { a unified information system. GNET@ can } \\
\text { provide a sub-set system for this group with } \\
\text { its existing databases. }\end{array}$ & $\begin{array}{l}\text { Contact established. GNET® } \\
\text { representative appointed as Member of their } \\
\text { Advisory Council. }\end{array}$ \\
\hline $\begin{array}{l}\text { National Aeronautics and Space } \\
\text { Administration Stennis Space Center }\end{array}$ & $\begin{array}{l}\text { This agency has requested that GNET® } \\
\text { promote remote sensing technologies for the } \\
\text { environment. They are reviewing the } \\
\text { potential of TechKnow as well as creation } \\
\text { of a VPN for their partners. }\end{array}$ & $\begin{array}{l}\text { Proposal submitted. Expected commitment } \\
\text { by } 6 / 98 \text {. }\end{array}$ \\
\hline $\begin{array}{l}\text { NOAA's Cooperative Institute for Coastal } \\
\text { and Estuarine Environmental Technologies } \\
\text { (CIEET) }\end{array}$ & $\begin{array}{l}\text { NOAA and the University of New } \\
\text { Hampshire administer this facility dedicated } \\
\text { to establishing a national network of "living } \\
\text { laboratories" among the national estuarine } \\
\text { research reserve system for applied } \\
\text { research, pilot projects, and applications for } \\
\text { new technologies. The CICEET's web site } \\
\text { and information capabilities are still in their } \\
\text { infancy. }\end{array}$ & $\begin{array}{l}\text { Partnering discussions initiated. Expected } \\
\text { commitment by } 9 / 98 \text {. }\end{array}$ \\
\hline $\begin{array}{l}\text { The National Wetlands Research Center } \\
\text { (NWRC) of the U.S. Geological Survey in } \\
\text { Lafayette, Louisiana }\end{array}$ & $\begin{array}{l}\text { NWRC's remote sensing, GIS, geospatial } \\
\text { capabilities as well as the emphasis on } \\
\text { partnership, outreach and technology } \\
\text { transfer offer a perfect fit for a GNET® } \\
\text { partnership. NWRC is also working on a } \\
\text { multitude of technology application and } \\
\text { commercialization activities, many of which } \\
\text { are in cooperation with NASA's Goddard } \\
\text { Space Flight Center and NASA Stennis. }\end{array}$ & $\begin{array}{l}\text { Partnership discussions have been held with } \\
\text { Center Director Dr. Robert Stewart. } \\
\text { Additional information was forwarded to } \\
\text { Dr. Stewart. Expected commitment by } 9 / 98 \text {. }\end{array}$ \\
\hline
\end{tabular}




\begin{tabular}{|c|c|c|}
\hline GNET@ Partner Target & Opportunity Description & Status \\
\hline $\begin{array}{l}\text { NOAA'S Office of Research and } \\
\text { Technology Applications (ORTA) }\end{array}$ & $\begin{array}{l}\text { This office is responsible for two programs } \\
\text { mandated by public laws: 1) NOAA's } \\
\text { technology transfer program, under the } \\
\text { Federal Technology Transfer Act of } 1986 \\
\text { and Department Of Commerce (DOC) } \\
\text { Small Business Innovation Research (SBIR) } \\
\text { program in accordance with the Small } \\
\text { Business Development Act of } 1992 \text {. This } \\
\text { web site is limited to the aforementioned } \\
\text { mission statement. Information quality and } \\
\text { quantity are lacking. GNET@'s, information } \\
\text { capabilities and user pool and would } \\
\text { integrate nicely with the GETE small } \\
\text { business assistance program. }\end{array}$ & $\begin{array}{l}\text { Partnering discussions initiated. Expected } \\
\text { commitment by } 9 / 98\end{array}$ \\
\hline $\begin{array}{l}\text { NOAA's Environmental Technology } \\
\text { Laboratory in Boulder, Colorado }\end{array}$ & $\begin{array}{l}\text { ETL - in existence for } 25 \text { years --supports } \\
\text { NOAA's environmental monitoring and } \\
\text { stewardship charter by performing oceanic } \\
\text { and atmospheric research and developing } \\
\text { new remote-sensing systems. ETL finds } \\
\text { innovative ways to use waves technologies } \\
\text { to study atmospheric and oceanic processes } \\
\text { and to probe regions that are not readily } \\
\text { accessible by direct measurement. ETL } \\
\text { web site is a good array of focused remote } \\
\text { sensing information and links. GNET® can } \\
\text { add value to ETL by broadening user- } \\
\text { groups and by developing potential } \\
\text { commercial markets for ETL technologies. } \\
\text { GNET® can assist ETL in demonstrating } \\
\text { remote sensing applications in partnership } \\
\text { with Stennis. }\end{array}$ & Contact established. \\
\hline $\begin{array}{l}\text { U.S. DOT National Technology } \\
\text { Deployment Initiative }\end{array}$ & $\begin{array}{l}\text { The reauthorization of ISTEA calls for the } \\
\text { establishment and implementation of a } \\
\text { national technology deployment initiative } \\
\text { and technology transfer program to address, } \\
\text { among other issues, sustainability of } \\
\text { transportation systems and reduce } \\
\text { environmental impact. The language also } \\
\text { calls for integration with and leveraging of } \\
\text { other such programs and Federal resources. } \\
\text { FHWA or RSPA will administer the } \\
\text { program. GNET® is such a resource and } \\
\text { can offer DOT partnership opportunities. }\end{array}$ & Contact established. \\
\hline $\begin{array}{l}\text { EPA Region III and FETC Water } \\
\text { collaboration }\end{array}$ & $\begin{array}{l}\text { EPA is entering into a memorandum of } \\
\text { understanding with FETC to support water- } \\
\text { related research, education, and outreach on } \\
\text { eight issue areas. Among the issues } \\
\text { included is the establishment of a physical } \\
\text { and virtual library of specified water data. } \\
\text { GNET® is well positioned to fulfill these } \\
\text { tasks and should be offered as the system to } \\
\text { house this data. }\end{array}$ & $\begin{array}{l}\text { Contact made with FETC/ CABE water } \\
\text { staff. }\end{array}$ \\
\hline
\end{tabular}




\begin{tabular}{|l|l|l|}
\hline \multicolumn{1}{|c|}{ GNET@ Partner Target } & \multicolumn{1}{|c|}{ Opportunity Description } & \multicolumn{1}{c|}{ Status } \\
\hline $\begin{array}{c}\text { ste Small Business Administration's SBIR } \\
\text { program }\end{array}$ & $\begin{array}{l}\text { GNET®'s information capability is far } \\
\text { more sophisticated. As part of SBIR, SBA's } \\
\text { popular electronic bulletin board, SBA, } \\
\text { online, has received over } 1.5 \text { million calls } \\
\text { since its inauguration in October 1992. } \\
\text { Combining user bases and integrating } \\
\text { GETE's Small Business Assistance } \\
\text { Program could significantly strengthen } \\
\text { GNET®. }\end{array}$ & Contact established. \\
& & \\
\hline
\end{tabular}

\section{Budget Savings Projections}

It is expected that current partnerships will reduce the FY99 projected GNET® costs to approximately $\$ 650,000$. However, an active FETC-GETF partnership could reduce the costs even further. It will be critical for FETC to become a partner in a GNETß component or two to show their support for the system. This will provide the Federal Agency "champion" required to successfully developing new partnerships. Once this is accomplished the targeting can be a joint effort.

The areas to reduce costs will be primarily in the maintenance and TechKnow areas. Any and all partners that leverage the system will be required to provide a prorated cost share to the total cost. For example, if our objective were to create 5 VPNs for partners, we would price the prorated share of system costs. It is our anticipation that each partner would pay a prorated share in the amount equal to 10 percent of those costs. This would reduce system costs to DOE by 50 percent. Similarly, those seeking to leverage TechKnow would be presented a proposal for similar costs. The system user would charge a system cost and customer service cost for the system. A sample grant proposal to EPA for TechKnow is located in Appendix I. In this example, GETF has proposed EPA contribute 36 percent of the total project budget to GNET® system maintenance.

In other areas content may be reviewed for cost savings. GETF has reduced these costs substantially but other gains can be made if a federal partner will become a content partner.

\section{$\square$ Partnership Outreach Plan}

GETF will create a basic introduction slide package (See Appendix III) that can be used by GETF and FETC in obtaining partners. Individual market sheets will also be created for TechKnow, Environmental VPNs, Environmental New Feeds, and Custom Web sites. The sheet will state proposal issues facing the partner and GNET® as the solution. A new section will be created on GNET® regarding partnership opportunities. The model appears to be working for the Earth Vision ${ }^{\mathrm{TM}}$ site. 


\section{$\square$ Conclusion}

A targeted growth strategy in which other federal partners can appropriately capitalize on existing GNET@ capabilities and investments will result in unparalleled information sharing and access to information on the environment and innovative environmental technologies. It will allow the system to support small business as they struggle to succeed. This site is a public service that will require ongoing federal contribution. Sustainability on the Internet based on subscription/sales is not yet possible.

$\square$ Appendix I - Sample GNET® Proposal \& Sample Partner Letter

$\square$ Appendix II - GNET® Supporting Materials

(Attachment of GNET® promotional materials)

$\square$ Appendix III - Draft Slide Presentation 


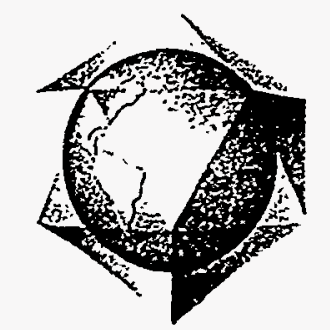

May 28, 1998

U.S. Environmental Protection Agency

Grants Operation Branch (3903F)

Grants Administration Division

$401 \mathrm{M}$ Street, SW

Washington, DC 20460

Attn: Ms. Lee

Re: Grant Assistance Request

Dear Ms. Lee:

Enclosed please find our request for grant assistance.

GETF has been working with Michael Forlini who is with the EPA Stratospheric Protection Division to prepare the scope and design of this project. Michael can be reached on (202) 564-9475.

If you have any questions regarding this request, or require additional information, please feel free to contact me at (703) 750-6401. Thank you in advance for your cooperation.

Sincerely,

William V. McSpadden

Director of Information Systems

Global Environment and Technology Foundation 
APPLICATION FOR

FEDERAL ABSISTANCE

\begin{tabular}{|c|c|c|c|}
\hline \multirow[b]{2}{*}{ Fit Non-Construction } & \multirow{2}{*}{$\begin{array}{l}\text { Prospolicetion } \\
\square \text { Construction } \\
\square \text { Non-Construction }\end{array}$} & 3. DATE RECETVEO OY STATE & State Appication bentidiox \\
\hline & & 4. DATE RECEIVEO OY FEDERUL NCEHCY & Foderal Itentition. \\
\hline
\end{tabular}

5. nencent information

Logumail Environment \& Technology Foundation

Address (orve cily, county, stale, and zip code):

7.010 Little River Turnpike, Suite 300

Annandale, VA 22003

Orgenketwornal thit:

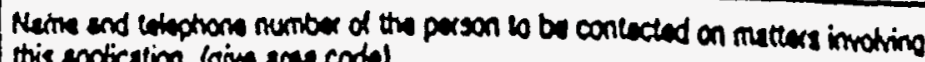
this explication (give ane codo)

Stuart Claggett, President OR

Bill McSpadden, (Acting) Director, Information Systems

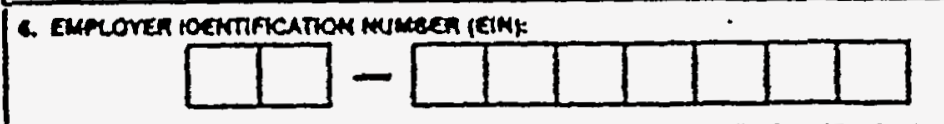

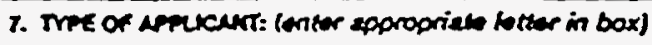
A. Serve
H. kndependers Sctrad Oixt.
B. County
L Sute Controled hetitution of Hepher Leaming
J. Privete Chiversity
C. Intricipal
D. Tounatio $K$ endien Trion
$E$ intorstate
L. knotidest
F. intormuricion
4. Profit Onganization
G. Sonciel Oistrict
N. Othen (Spaty): Non-Profit

a Tree of APMucatione

Q1New $\square$ Continuation $\square$ Provision

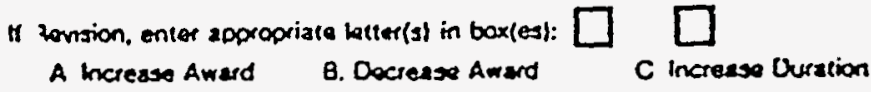

O Decresen Duration Oriner (spocity):

9. reurs of reocines noenct:

Environmental Protection Agency

19. CATMLO of FEOERiL DOMESTK

ASSTSTANCE MUMEER

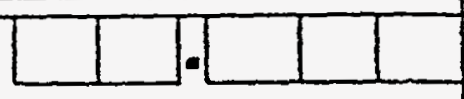

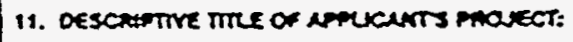

กTE:

Creation of an Ozone Depleting Substances

(ODS) Technologies Management and

Communication System

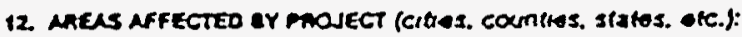

United States \& Worldwide

\begin{tabular}{|c|c|c|c|}
\hline mopos & & 4. comanesshomul distracts of. & \\
\hline sure Date & Ending Date & a..Apoticans & b. Proiect \\
\hline June 1,1998 & May 30,199 & Virginia - 10th District & 10th District \\
\hline
\end{tabular}

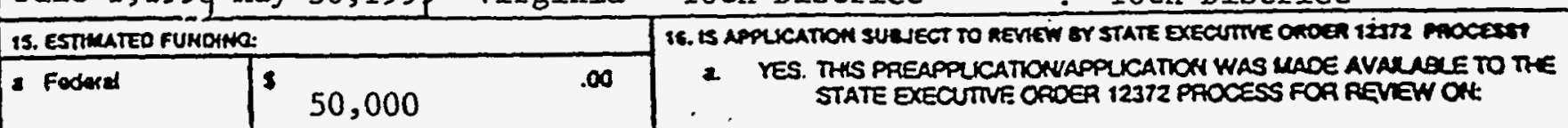

\begin{tabular}{|l|l|l|l|}
\hline 6. Applicent & 50,000 & \\
\hline & $\$$ & OATE
\end{tabular}

\begin{tabular}{|c|c|c|c|}
\hline c sencen & $\$$ & .00 & NO. D PROGRAM is NOT COVERED BY EO. 12372 \\
\hline A Locd & \$ &.$\infty$ & OA PACORAM HUS NOT BEEN SEECTED BY STATE FOA \\
\hline - Orther & $\$$ &.$\infty$ & $\cdot$ \\
\hline 1. Proorem hoome & 8 &. & \multirow{2}{*}{ 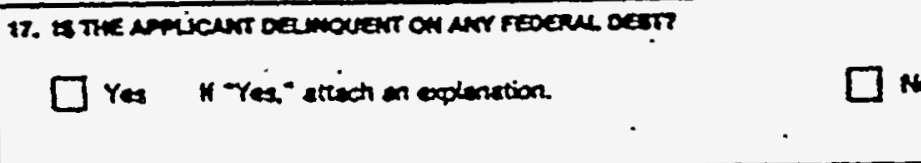 } \\
\hline g TOTAL & * 50,000 &.$\infty$ & \\
\hline
\end{tabular}

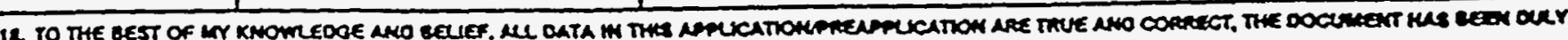

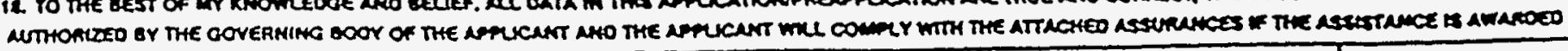

\begin{tabular}{|c|c|c|}
\hline $\begin{array}{l}\text { a. Tyood Nam of Authorized Reprosentative } \\
\text { Stuart Claggett }\end{array}$ & $\begin{array}{l}\text { b. Tite } \\
\text { President }\end{array}$ & $\begin{array}{l}\text { c. Toluphom mumber } \\
(703) 750-6401\end{array}$ \\
\hline o Sognature of Authorized Represontzive & & e. Date Signed \\
\hline
\end{tabular}




\section{Ozone Depleting Substances Technology Database}

\section{Description of Project:}

\section{Problem Definition:}

Protection of the stratosphere is a critical issue affecting all walks of life. The issue is a global one because actions of countries on one side of the planet affect the stratospheric ozone of another. There is increasing scientific consensus that ambient levels of UV radiation at the earth's surface are expected to rise due to the predicted decrease in the stratospheric ozone layer. Elevated levels of UV exposure (in particular UVb) have been associated with increases in malignant melanoma and nonmalignant melanoma, cataracts, impaired human immune systems, damaged crops and reduced fishery yield. Overwhelming evidence demonstrates that certain chemicals destroy the ozone layer, earth's protection from dangerous UVb. Trace gases including chlorofluorocarbons, otherwise know as CFCs and HCFC have contributed to this problem.

It is widely believed that the increases in contributions of CFCs and other Ozone Depleting Substances are deleteriously affecting the earth's ozone layer, thereby contributing to the global warming problem. While the science surrounding atmospheric pollution and the causes and effects of climate change continue to be researched, studied and debated, there is an ever-present need to collect technological information which will be used to make intelligent, informed decisions in finding solutions to the problem. One known factor in preventing further erosion of the earth's atmospheric layer is the effective management of Ozone Depleting Substances (including CFC) technologies. These chemicals have been shown to be one of the major contributors to ozone depletion and their effective, responsible management in the future will be a key component of our future success in preserving the ozone layer.

\section{GETF Qualifications/Approach:}

The Global Environment \& Technology Foundation, a 501C(3) not-for-profit corporation, has been a leader in and has amassed extensive experience in developing management solutions by creating, designing and implementing innovative databases and management-systems over the internet. The mission of the Foundation is to "...foster innovation by uniting environment, technology and enterprise to encourage sustainable practices throughout the world". One of the basic premises of GETF is that the effective flow, management, and communication of environmental information is essential to achieving the goal of sustainable development. To address this problem, GETF created GNET; a World Wide Web (WWW) based communications network providing links to information in the environmental technology areas and for environmental information in general. In building this electronic information framework, GETF is now in the unique position to expand its network and to leverage its resources to tackle new and emerging environmental problems and technologies. Historically, GETF technology databases have been developed around remediation technologies and have recently expanded into other areas. GETF is now embarking on a global climate change initiative, and believes that the collection, identification and dissemination of technologies which can reduce or prevent depletion of the ozone layer would provide invaluable management information for environmental decision makers among all stakeholder groups. GETF proposes to use its existing 
electronic network architecture to create and implement a database for the effective management of ozone depleting substances (including CFC) technologies. This database would promote effective ODS and CFC management and destruction by collecting information about various technologies and techniques from within the U.S. and from other countries and by publishing this data to all interested parties via the internet. The internet is the most effective way to do this since the information can come directly from technology holders and developers and then can be redeployed through the internet on a world-wide basis.

\section{Results or Benefits Expected:}

The primary objective of the project is to develop a management and communication tool for use by the Foundation, federal, state and local governments, the private sector and private individuals, and by international organizations concerned about the effects of ODS on the environment. A secondary objective is to increase awareness among stakeholders about the progress and problems associated with tackling this enormous problem. A third objective is to allow technology holders to promote their technologies on a world-wide basis and in an already existing environment.

The benefit to all stakeholders is expected to be the implementation of a reliable, cost-effective management and communication tool for use by environmental decision makers and the public alike whereby new and innovative technologies for the destruction of ozone depleting substances are identified and information disseminated.

\section{Workplan Approach:}

To meet the challenges discussed above, GETF proposes to do the following:

1. Create a database structure inside the existing TechKnow database for Ozone Depleting Substances (including CFC) destruction technologies that is deployed over the internet. The database will be easy to use with no training or instruction required. It will be fully searchable and will be available to anyone on the globe with an internet connection.

2. Use the data format provided by USEPA's Stratospheric Protection Division. The data fields will be designed with the user in mind to create an informative starting point to allow users to narrow down the technologies that they want to investigate further. The data will include links to technology owners so that the user can go directly to the source for technical data.

3. Allow the entry of ODS destruction technologies by technology developers using a standard browser from anywhere in the world via the internet. The best source of information on high tech processes are the owners of the processes themselves. The system will allow them to enter their data directly and will allow them to modify that data as their technology changes and develops.

4. Configure the database structure such that all the data can be moderated prior to being seen by the public. In order to assure the integrity of the database, all data entered will go into a moderation cue where it will be reviewed prior to making it available for viewing by the general public. Emails will be automatically generated by the application to alert the moderators to initiate the reviews for new or edited entries. 
5. Construct a password-protected moderation function that can be implemented by third parties over the internet using a standard web browser. By setting up the moderation function via a browser, anyone with the appropriate level of access could moderate the database from anywhere in the world.

6. Construct a mechanism that sends email to technology vendors reminding them to update their technology information. In the high tech arena, information becomes old and outdated very rapidly. The system will be able to send emails to technology owners on a periodic basis reminding them to periodically edit their technologies.

7. Create a password scheme that allows technology developers to update database records via the internet.

8. Create an area where selected governmental and third party organizations can comment on and provide certification/verification information concerning specific technologies. A comment area for validation and certification will be included that can only be edited by selected parties. This will be implemented to hold certification or verification data if such a program is initiated in the future.

9. Promote the database through current ongoing efforts. GETF promotes TechKnow and its other web sites on a regular basis. GETF intends to highlight this ODS/CFC technology management database on its EarthVision and GNET systems.

10. The site will link to EPA's web pages where ever possible and GETF will work with EPA's web department to make sure that this page has links and is prominently featured on EPA's electronic sites.

\section{General Project Information:}

GETF has an existing technology database called TECHKNOW that is currently deployed on the internet through a cooperative agreement with the Department of Energy. This database allows environmental remediation technology holders to enter information in a moderated database structure.

1ง:

Through interaction with the remediation community since the first deployment of TechKnow, GETF became aware of the need to expand the database to include other types of environmental technologies. In order to accomplish this, GETF began to work on Version 2. This new version will be much easier to use and will allow the database to be broken down into separate databases while still keeping the same architecture.

GETF will use Claris Filemaker Pro 4.0 to develop the basic level file structures as well as the operational scripting. The HTML interface that will make the database accessible through the web will be developed using Claris Home Page 2.0. The database will be deployed on a GETF owned internet web server at the IP address of 204.255.211.100:591. The CFC data will be one of several data sets that will be deployed as part of the new Techknow. GETF maintains its own staff of database designers and internet web programmers. Individuals in these disciplines are 
also assisted by outside consultants from time to time depending on the task and the existing workload.

The project will be managed by William McSpadden who is the Director of Information Systems at GETF. Mr. McSpadden is uniquely qualified to manage this project because of his design and management role in the deployment of Techknow - Version 2. In addition to Techknow, Mr. $\mathrm{McSpadden}$ manages all of the other web sites and web enabled databases for GETF.

\section{Quality Assurance:}

GETF places a very high premium on the quality and reliability of the software operating systems it designs and in the quality of the information displayed on its networks. Extensive testing is utilized to identify any platform problems prior to releasing the information or publishing the URL on the web. Also, GETF includes a comment email box and encourages users to comment on any problems that they may encounter so that the root cause of the difficulty can be determined and quickly resolved.

All data entered into the databases via the web goes into a moderation queue and is not visible on the web. On a regular basis, a GETF moderator checks the database to review any pending entries. While GETF does not verify claims made by technology developers, the entries are reviewed for completeness, accuracy, and relevance. Any entries that do not conform are rejected and a message is sent to the author requesting revisions. A record is only visible on the web after the moderator has approved it.

\section{Project Budget:}

Please see the following pages which identify tasks and budget for this project. 
Standard Form 424A

OMB Approval No. 0348-0044

Budget Information - Non-Construction Programs

\begin{tabular}{|c|c|c|c|c|c|c|}
\hline \multicolumn{7}{|c|}{ Section A - Budget Summary } \\
\hline \multirow{2}{*}{$\begin{array}{c}\text { Grant Program } \\
\text { Function or } \\
\text { Activity } \\
\{a\} \\
\end{array}$} & \multirow{2}{*}{$\begin{array}{c}\text { Catalog of Federal } \\
\text { Domestic Assistance } \\
\text { Number } \\
\{b\} \\
\end{array}$} & \multicolumn{2}{|c|}{ Estimated Unobligated Funds } & \multicolumn{3}{|c|}{ New or Revised Budget } \\
\hline & & $\begin{array}{l}\text { Federal } \\
\{c\}\end{array}$ & $\begin{array}{l}\text { Non-Federal } \\
\{\text { d }\}\end{array}$ & $\begin{array}{c}\text { Federal } \\
\{\mathrm{e}\}\end{array}$ & $\begin{array}{c}\text { Non-Federal } \\
\{f\}\end{array}$ & $\begin{array}{c}\text { Total } \\
\{g\} \\
\end{array}$ \\
\hline 1 ODS Technologies & & $49,897.91$ & 0.00 & & & $49,897.91$ \\
\hline 2 & & & & & & 0.00 \\
\hline 3 & & & & & & 0.00 \\
\hline 4 & & & & & & 0.00 \\
\hline 5. Totals & & $\$ 49,897.91$ & $\$ 0.00$ & $\$ 0.00$ & $\$ 0.00$ & $\$ 49,897.91$ \\
\hline \multicolumn{7}{|c|}{ Section B - Budget Categories } \\
\hline \multirow{2}{*}{\multicolumn{2}{|c|}{ 6.Object Class Categories }} & \multicolumn{4}{|c|}{ Grant Program, Function or Activity } & \multirow[b]{2}{*}{ Total } \\
\hline & & $\{1\}$ & $\{2\}$ & $\{3\}$ & $\{4\}$ & \\
\hline \multicolumn{2}{|l|}{ a.Personnel } & $5,799.46$ & & & & $5,799.46$ \\
\hline \multicolumn{2}{|l|}{ b.Fringe Benefits ( $40 \%)$} & $2,319.78$ & & & & $2,319.78$ \\
\hline \multicolumn{2}{|l|}{ c.Travel } & 0.00 & . & & & $\ldots \quad .0 .00$ \\
\hline \multicolumn{2}{|l|}{ d.Equipment } & 0.00 & & & & 0.00 \\
\hline \multicolumn{2}{|l|}{ e.Supplies } & $6,521.74$ & & & & $6,521.74$ \\
\hline \multicolumn{2}{|l|}{ f.Contractual } & $23,600.00$ & & & & $23,600.00$ \\
\hline \multicolumn{2}{|l|}{ g.Construction } & 0.00 & & & & 0.00 \\
\hline \multicolumn{2}{|l|}{ h.Other-Grants } & 0.00 & & & & 0.00 \\
\hline \multicolumn{2}{|c|}{ i.Total Direct Charges (sum 6a-6h) } & $38,240.98$ & 0.00 & 0.00 & 0.00 & $38,240.98$ \\
\hline \multicolumn{2}{|l|}{ j.Indirect Charges } & $11,656.93$ & & & & $11,656.93$ \\
\hline \multicolumn{2}{|c|}{ k.Totals (sum of $6 i$ and $6 j$ ) } & $\$ 49,897.91$ & $\$ 0.00$ & $\$ 0.00$ & $\$ 0.00$ & $49,897.91$ \\
\hline \multicolumn{2}{|l|}{ 7.Program Income } & $\$ 0.00$ & $\$ 0.00$ & $\$ 0.00$ & $\$ 0.00$ & $\$ 0.00$ \\
\hline
\end{tabular}


Standard Form 424A (cont'd)

Section C - Non-Federal Resources

\begin{tabular}{|c|c|c|c|c|c|}
\hline \multicolumn{6}{|c|}{ Section C-Non-Federal Resources } \\
\hline \multicolumn{2}{|l|}{ (a) Grant Program } & (b) Applicant & (c) State & (d) Other Sources & (e) Totals \\
\hline \multicolumn{2}{|l|}{8} & & & 0.00 & 0.00 \\
\hline \multicolumn{2}{|l|}{9} & & & & 0.00 \\
\hline \multicolumn{2}{|l|}{10} & & & & 0.00 \\
\hline \multicolumn{2}{|l|}{11} & & & & 0.00 \\
\hline \multicolumn{2}{|l|}{ 12.Total (sum of lines $8-11$ ) } & $\$ 0.00$ & $\$ 0.00$ & $\$ 0.00$ & $\$ 0.00$ \\
\hline \multicolumn{6}{|c|}{ Section D - Forecasted Cash Needs } \\
\hline \multirow[t]{2}{*}{ 13.Federal } & Total for 1st Year & 1st Quarter & 2nd Quarter & 3rd Quarter & 4th Quarter \\
\hline & $49,897.91$ & $42,413.23$ & $2,494.90$ & $2,494.90$ & $2,494.90$ \\
\hline 14.Non-Federal & 0.00 & 0.00 & 0.00 & 0.00 & 0.00 \\
\hline 15.Total (sum of lines 13 and 14) & $\quad 49,897.91$ & .......... $42,413.23$ & $2,494.90$ & $2,494.90$ & $2,494.90$ \\
\hline \multicolumn{6}{|c|}{ Section E-Budget Estimates of Federal Funds Needed for Balance of the Project } \\
\hline \multirow{2}{*}{\multicolumn{2}{|c|}{ (a) Grant Program }} & \multicolumn{4}{|c|}{ Future Funding Periods } \\
\hline & & (b) First & (c) Second & (d) Third & (e) Fourth \\
\hline \multicolumn{2}{|l|}{16} & $\ldots \ldots$ & & & \\
\hline \multicolumn{6}{|c|}{$\cdots-\cdots$} \\
\hline \multicolumn{6}{|l|}{18} \\
\hline \multicolumn{6}{|l|}{19} \\
\hline \multicolumn{2}{|l|}{ 20.Total (sum of lines 16-19) } & $\$ 0.00$ & $\$ 0.00$ & $\$ 0.00$ & $\$ 0.00$ \\
\hline \multicolumn{6}{|c|}{ Section F - Other Budget Information } \\
\hline 21.Direct Charges: & & 22.Indirect Charges: & $13,976.71$ & & \\
\hline
\end{tabular}

Authorized for Local Reproduction Standard Form 424A (Rev.4-92) Page 2 
TASK \#1

Design Database Structure

GETF will work with EPA personnel to design the data record to capture the information topical to CFC management. The data design will include the number of fields, the data types, and the size of the fields.

\section{TASK \#2}

Implement Design

Once the base level design has been established. GETF will develop the necessary programming to add this data set to the current Filemaker Pro application. This will include writing operational scripts and designing data layouts and relationships.

\section{TASK \#3}

Perform HTML Programming to bring to the web.

After the database structure has been implemented and tested on the server, the HTML code will be written that will deploy it over the internet. This code will facilitate all of the functionality that is described in the statement of work.

TASK \#4

Testing and Deployment

This is the last step prior to making the system available to the general public. Extensive testing will be performed to identify any operational or navigational errors. The errors will be corrected and the site will be made live on the internet.

TASK \#5

Integration and Promotion

GETF will integrate this database into the existing Techknow platform. It will be promoted through Earthvision and GNET. Additionally, it will be promoted as part of the entire Earthvision platform.

\section{TASK \#6}

Internet connectivity and hosting

GETF will provide internet Filemaker Pro web site and database hosting for the period of one year. This will include internet connectivity, maintenance, software upgrades, and routine backups. GETF will provide a year of telephone customer support to users and will moderate the database for a year. 
Task \#1

Design Database structure

Desc.

Rate Hrs Extension

Sr Project Manager $\quad \$ 92.00 \quad 40 \quad \$ 3,680.00$

Sr. Filemaker Consultant $\quad \$ 92.00 \quad 10 \quad \$ 920.00$

Database Programmer $\quad \begin{array}{llll}\$ 33.16 & 30 & \$ 994.80\end{array}$

HTML Programmer $\quad \$ 32.08 \quad \$ 0.00$

Jr. Programmer $\quad \$ 27.60 \quad \$ 0.00$

TASK TOTAL

$\$ 5,594.80$

Task \#2

Perform programming to implement structure within Database

Desc.

Rate Hrs Extension

Sr Project Manager

$\$ 92.00 \quad 35 \quad \$ 3,220.00$

Sr. Filemaker Consultant $\quad \$ 92.00 \quad 80 \quad \$ 7,360.00$

Database Programmer $\$ 33.16 \quad \$ 0.00$

HTML Programmer $\quad \$ 32.08 \quad \$ 0.00$

Jr. Programmer $\quad \$ 27.60 \quad \$ 0.00$

TASK TOTAL

$\$ 10,580.00$

Task \#3

Perform HTML progrmming to bring to the web

Desc.

Rate Hrs Extension

Sr Project Manager

$\$ 92.00 \quad 20 \$ 1,840.00$

Sr. Filemaker Consultant

$\$ 92.00 \quad \$ 0.00$

Database Programmer

$\$ 33.16 \quad \$ 0.00$

HTML Programmer

$\$ 32.08 \quad 80 \quad \$ 2,566.40$

Jr. Programmer

$\$ 27.60$

$\$ 0.00$

TASK TOTAL

$\$ 4,406.40$

Task \#4

Testing and Deployment

Desc.

Sr Project Manager

Rate Hrs Extension

$\$ 92.0020 \$ 1,840.00$

Sr. Filemaker Consultant $\quad \$ 92.00 \quad 20 \$ 1,840.00$

Database Programmer

$\$ 33.16 \quad 20 \quad \$ 663.20$

$\$ 32.08 \quad 40 \$ 1,283.20$

HTML Programmer

$\$ 27.60$

$\$ 0.00$

TASK TOTAL

$\$ 5,626.40$

Task \#5

Integration into Techknow and GNET. Promotion via GNET and EV, to EPA web pages

Desc.

Sr Project Manager

Rate Hrs Extension

Sr. Filemaker Consultant

$\$ 92.00 \quad 20 \quad \$ 1,840.00$

Database Programmer

$\$ 92.00 \quad \$ 0.00$

HTML Programmer

$\$ 33.16 \quad 31 \quad \$ 1,027.96$

Jr. Programmer

$\$ 32.08 \quad 40 \quad \$ 1,283.20$

$\$ 27.60 \quad \$ 0.00$ 
Task \#6

Internet Connectivity and hosting for 1 year.

Desc.

Rate Hrs Extension

Sr Project Manager

Sr. Filemaker Consultant

$\$ 92.00 \quad 50 \$ 4,600.00$

Database Programmer $\$ 92.00 \quad \$ 0.00$

$\$ 33.16 \quad \$ 0.00$

HTML Programmer $\$ 32.08$

$\$ 0.00$

Jr. Programmer

$\$ 27.60 \quad 200 \$ 5,520.00$

Hosting and Maint.

TASK TOTAL

$\$ 625.00 \quad 12 \$ 7,500.00$

SUBTOTAL

$\$ 47,978.76$

FEE @ 4\%

$\$ 1,919.15$

TOTAL ESTIMATE

$\$ 49,897.91$ 


\author{
William V. McSpadden \\ 7306 Quantum Leap Lane, Bowie, MD 20720 \\ (T) 301-464-0211 (F) 301-464-8416 MCSPADDE@EROLS.COM
}

\title{
SUMMARY OF QUALIFICATIONS
}

Fourteen years of technical and business management experience. Operational and $\mathrm{P} / \mathrm{L}$ responsibility for multiple offices with large budgets. Proven ability to acquire and manage large accounts, deliver profitability, maintain operational efficiency, and manage diverse groups.

\section{WORK HUSTORY}

District Operations Manager \& General Manager, Clean Harbors Environmental Services Inc., Responsible for the Operational Management of the Southern Mid-Atlantic District and the South Eastern District. Included management of offices in Baltimore, Richmond, Charleston, Philadelphia, and Atlanta. Senior Management position with a national publicly held service company. 8/92 to present. Salary: $\$ 85,000$ plus performance bonus plus company car.

Vice President, REMAC USA, Inc. and Vice President of Operations, Eastern Chemical Waste Systems, Inc. (ECWS). Managed all aspects of a major remeadiation company with numerous offices and over $\$ 7.5$ million in annual sales and managed the operational activities of ECWS, a large hazardous waste transportation and disposal interest that shared joint ownership with REMAC. 7/89 to 8/92.

Vice President, VOLTA Environmental Services, Inc., a subsidiary of REMAC/ECWS. Managed all operational and business aspects of this PCB cleanup contractor until promoted to the position above. $7 / 88$ to $7 / 89$.

Division Manager, ATEC Associates, Inc. Managed a staff of over 32 technicians, managers and support staff in a division which provided environmental and geotechnical testing services. This division produced 1.5 million in annual sales with a profit margin of $19.3 \%$. Honored with Division Manager of the Year award in 1986. Division Manager position was obtained after numerous promotions (Field Tech to Asst. Project Manager to Project Manager to Division Manager). 7/83 to 7/88.

\section{EXPERIENCE}

\section{BUSINESS DEVELOPMENT}

Developed, implemented and maintained computer costing systems to price proposals and to track actual project performance.

Designed sales territories, hired sales reps., and directly managed their performance.

Successfully won major projects in the public and private sectors. Specific examples include a $\$ 2.4$ million award from Bethlehem Steel, \$1.8 million award from Roy F. Weston, a \$3.8 award from Exxon, and \$5.8 million award from Amoco.

Developed and maintained large corporate accounts with PEPCO, BG\&E, EXXON, and GE. 


\section{OPERATIONS}

Managed day to day operations for multiple offices in the US and in Puerto Rico.

Implemented and managed a daily resource utilization system to promote up-time and effective resource sharing between multiple locations.

Developed and implemented an extensive OSHA training course as well as numerous other continuing technical development training programs.

Specified, purchased, and managed a large fleets of trucks, and specialized service equipment.

\section{FINANCE}

Have had profit and loss responsibilities for multiple offices. Have extensive experience with financial management and reporting in both public and private companies.

Negotiated with banks for bonding, letters of credit, increases in credit lines, project specific financing, and construction financing.

Played a significant role in a loan "work-out" which avoided an impending Chapter 11 filing.

\section{MANAGEMENT}

Have experience working in a sole proprietorship reporting directly to the owner and as a member of an Executive Committee in a large publicly traded corporation.

Have routinely managed a multiple office district or territory.

Have participated in or managed both the opening and the closing of offices as well as reengineering, layoffs, acquisitions, and spin-offs.

\section{LEGAL}

Managed the defense of suits filed against the company for wrongful discharge, EOE discrimination, disability, and other related claims.

(in

Initiated and defended suits relating to breach of contract, payment disputes, enforcement of noncompete agreements, and other civil matters.

Managed defenses against civil and criminal charges arising from alleged violations of OSHA, DOT, and EPA regulations.

\section{PERSONAL}

Bachelors degree in Environmental Science from The University of Virginia, 1983. Married with 2 children. Excellent computer skills including Web Page design. Currently own a tea distributorship operated as a home business and hobby with my wife. Very active in water sports. Willing to travel or relocate. 35 years old. 


\section{KEY CONTACTS}

Authorized Representatives: Original awards and amendments will be sent to this individual for review and acceptance, unless otherwise indicated.

$\begin{array}{ll}\text { Name: } & \text { Stuart Claggett } \\ \text { Title: } & \text { President }\end{array}$

Complete Address: Global Environment \& Technology Foundation

7010 Little River Turnpike, Suite 300, Annandale, VA 22003

Phone Number. (703) 750-6401 Fax: (703) 750-6506

E-Mail Address: stuart.claggettdgetf.org

Payee: Individual authorized to accept payments.

\begin{tabular}{ll} 
Name: & Stuart Claggett \\
Tite: & President \\
\hline
\end{tabular}

Complete Address: Same as Above

Phone Number:

E-Mail Address:

Fax:

Administrative Contact: Individual from Sponsored Programs Office to contact concerning administrative matters (i.e., indirect cost rate computation, rebudgeting requests, etc.)

Name: Bill McSpadden

Title: (Acting) Director, Information Systems

Complete Address:- Global Envïroñment \& Technology Foundation

7010 Little River Turnpike, Suite 300, Annandale, VA 22003

Phone Number: (703) 750-6401_Fax: (703) 750-6506

E-Mail Address: bil1.mcspaddendgetf.org

Project Manager: Individual responsible for the technical completion of the proposed work.

Name:__ Bil1 McSpadden

Title: See Above

Complete Address:_ Same as Above

Phone Number:

Fax:

E-Mail Address: 


\section{United States Environmental Protection Agency Washington, DC 20460 \\ Certification Regarding Debarment, Suspension, and Other Responsibility Matters}

The prospective participant certifies to the best of its knowledge and belief that it and the principals:

(a) Are not presently debarred, suspended, proposed for debarment, declared ineligible, or voluntarily excluded from covered transactions by any Federal department or agency;

(b) Have not within a three year period preceding this proposal been convicted of or had a civil judgement rendered against them for commission of fraud or a criminal offense in connection with obtaining, attempting to obtain, or performing a public (Federal, State, or local) transaction or contract under a public transaction: violation of Federal or State antitrust statutes or commission of embezzlement, theft, forgery, bribery, falsification or destruction of records, making false statements, or receiving stolen property:

(C) Are not presently indicted for or otherwise criminally or civilly charged by a government entity (Federal, State, or local) with commission of any of the offenses enumerated in paragraph (1)(b) of this certification; and

(d) Have not within a three-year period preceding this application/proposal had one or more public transactions (Federal, State, or local) terminated for cause or default.

I understand that a false statement on this certification may be grounds for rejection of this proposal or termination of the award. In addition, under 18 USC Sec.1001, a false statement may result in a fine of up to $\$ 10,000$ or imprisonment for up to 5 years, or both.

Stuart Claggett, President

Typed Name \& Title of Authorized Representative 


\begin{tabular}{|cc|c|}
\hline UNITED STATES ENVIRONMENTALPROTECTIONAGENCY & WASHINGTON, DC 20460 & Form Approved \\
OMB No.2090-0014 & Expires 4-30-99
\end{tabular}

Note: Read instructions on reverse side before completing form.

\begin{tabular}{l|ll} 
I. 1. Applicant (Name, City, State) & B. Recipient & (Name, City, State)
\end{tabular}

Global Environment \& Technology same as $\|_{1}$ A

Turnpike, Suite 300, Annandalel, VA 22003

II. Brief description of proposed project, program or activity.

Creation of an Ozone Depleting Substances (ODS) Technologies Management \& Commulicatior

III. Are any civil rights lawsuits or complaints pending against applicantand/or recipient?

If "yes", list those complaints and the disposition of each complaint.

C. EPA Project No.

IV. Have any civil rights compliance reviews of the applicant and/or recipient been conducted

by any Federal agency during the two years prior to this Application for activities wrich

YES $\mathrm{X}$ NO

System

would receive EPA assistance?

If "yes", list those compliance reviews and status of each review.

V. Is any other Federal financial assistance being applied for or is any other Federal financial assistance being applied to any portion of this project, program or activity?

YES $\mathrm{X}$ NO

If "yes", list the other Federal Agency(s), describe the associated work and the dollar amount

of assistance.

VI. If entire community under the applicant's jurisdiction is not served under the existing facilitiesl

services, or will not be served under the proposed plan, give reasons why.

Project will benefit worldwide community

\begin{tabular}{|l|l|l}
\hline VII. & Population Characteristics & Number of Peopla \\
\hline
\end{tabular}

1. A. Population of Entire Service Area Worldwide community impact

B. Minority Population of Entire Service Area

2. A. Population Currently Being Served

B. Minority Population Currently Being Served

3. A. Population to be Served by Project, Program or Activity

B. Minority Population to be Served by Project, Program or Activity

4. A. Population to Remain Without Service

B. Minority Population to Remain Without Service

VII. Will all new facilities or alterations to existing facilities financed by these funds be designed and constructed to be readily accessible to and usable by handicapped persons? If "No", explain how a regulatory exception applies (40 CFR 7.70).

$$
\mathrm{N} / \mathrm{A}
$$

IX. Give the schedule for future projects, programs or activities (or of future plans), by which service will be provided to all beneficiaries within applicant's jurisdiction. If there is no schedule, explain why.

This is a one-time project for Database and Systems Development

$X$. I certify that the statements I have made on this form and all attachments thereto are true, accurate and complete. I acknowledge that any knowingly false or misleading statement may be punishable by fine or imprisonment or both under applicable law.

\begin{tabular}{|l|l|c|}
\hline A. Signature of Authorized Official . & $\begin{array}{c}\text { B. Title of Authorized Official } \\
\text { President, GETF }\end{array}$ & C. Date \\
\hline Approved & For the U.S. Environmental Protection Agency & Date \\
\hline
\end{tabular}


EPA PROJECT CONTROL NUMBER

\section{CERTIFICATION REGARDING LOBBYING}

CERTIEICATION FOR CONTACTS, GRANTS, LOANS, AND COOPERATIVE AGREEMENTS

The Undersigned certifies, to the best of his or her knowledge and belief, that:

(1) No Federal appropriated funds have been or will be paid, by or on behalf of the undersigned, to any person for influencing or attempting to influence an officer or employee of any agency, a Member of Congress, an officer or employee of Congress, or an employee of a Member of Congress in connection with the awarding of any Federal contract, the making of any Federal grant, the making of any Federal loan, the entering into of any cooperative agreement, and the extension, continuation, renewal, amendment, or modification of any Federal contract, grant, loan, or cooperative agreement.

(2) If any funds other than Federal appropriated funds have been paid or will be paid to any person for influencing or attempting to influence an officer or employee of any agency, $a$ Member of Congress, or an employee of a Member of Congress in connection with this Federal contract, grant, loan, or cooperative agreement, the undersigned shall complete and submit Standard Form-ILL, "Disclosure Form to Report Lobbying," in accordance with its instructions.

(3) The undersigned shall require that the language of this certification be included in the award of documents for all subawards at all tiers (including subcontracts, subgrants, and contracts under.grants, loans, and cooperative agreements) and that all subrecipients shall certify and disclose a"cordingly.

This certification is a material representation of fact upon which reliance was placed when this transaction was made or entered into. Submission of this certification is a prerequisite for making or entering into this transaction imposed by section 1352, Title 31, U.S. Code. Any person who fails to file the required certification shall be subject to a civil penalty of not less than $\$ 10,000$ and not more than $\$ 100,000$ for each such failure.

Stuart Claggett, President TYPED NAME \& TITLE OF AUTHORIZED REPRESENTATIVE 


\section{ASSURANCES - NON-CONSTRUCTION PROGRAMS}

Note: Certain of these assurances may not be applicable to your project or program. If you have questions, please contact the awarding agency. Further, certain Federal awarding agencies may require applicants to certify to additional assurances. If such is the case, you will be notified.

As the duly authorized representative of the applicant I certify that the applicant:

1. Has the legal authority to apply for Federal assistance, and the institutional, managerial and financial capability (including funds sufficient to pay the non-Federal share of project costs) to ensure proper planning, management and completion of the project described in this application.

2. Will give the awarding agency, the Comptroller General of the Urited States, and if anpropriate. the State, through any authorized representative, access to and the right to examine all records, books, papers, or documents related to the award: and will establish a proper accounting system in accordance with generally accepted accounting standards or agency directives.

3. Will establish safeguards to prohibit employees from using their positions for a purpose that constitutes or presents the appearance of personal or organizational conflict of interest, or personal gain.

4. Will initiate and complete the work within the applicable time frame after receipt of approval of the awarding agency.

5. Will comply with the Intergovernmental Personnel Act of 1970 (42 U.S.C. \$\$ 4728-4763) relating to prescribed standards for merit systems for programs funded under one of the nineteen statutes or regulations specified in Appendix $A$ of OPM's Standards for a Merit System of Personnel Administration (5 C.F.R. 900, Subpart F).

6. Will comply with all Federal statutes relating to nondiscrimination. These include but are not limited to: (a) Title VI of the Civil Rights Act of 1964 (P.L. 88-352) which prohibits discrimination on the basis of race, color or national origin; (b) Title IX of the Education Amendments of 1972, as amended (20 U.S.C. \$\$ 1681-1683, and 1685-1686). which prohibits discrimination on the basis of sex; (c) Section 504 of the Rehabilitation Act of 1973, as amended (29 U.S.C. 794), which prohibits discrimination on the basis of handicaps; (d) the Age Discrimination Act of. 1975, as amended (42 U.S.C. $\$ 6101-6107)$, which prohibits diserimination on the basis of age: (e) the Drug Abuse Office and Treatment Act of 1972 (P.L. 92-255), as amended, relating to nondiscrimination on the basis of drug abuse; $(D$. the Comprehensive Alcohol Abuse and Alcoholism Prevention. Treatment and Rehabilitation Act of 1970 (P.L. 91-616), as amended, relating to nondiscrimination on the basis of alcohol abuse or alcoholism; $(\mathrm{g}) \$ 523$ and 527 of the Public Health Service Act of 1912 (42 U.S.C. 290 dd-3 and 290 ee$3)$, as amended, relating to confidentiality of alcohol and drug abuse patient records; (h) Title VIII of the Civil Rights Act of 1968 (42 U.S.C. 3601 et seq.), as amended, relating to nondiscrimination in the sale, rental or financing of housing: (i) any other nondiscrimination provisions in the specific statute(s) under which application for Federal assistance is being made; and (j) the requirements of any other nondiscrimination statute(s) which may apply to the application.

7. Will comply, or has already complied, with the requirements of Titles II and III of the Uniform Relocation Assistance and Real Property Acquisition Policies Act of 1970 (P.L. 91-646) which provide for fair and equitable treatment of persons displaced or whose property is acquired as a resuit of Federal or federally assisted programs. These requirements apply to all interests in real property acquired for project purposes regardless of Federal participation in purchases.

8: Will comply with the provisions of the Hatch Act (5 U.S.C. \$\$ 1501-1508 and 7324-7328) which limit the political activities of employees whose principal employment activities are funded in whole or in part with Federal funds.

9. Will comply, as-applicable, with the provisions of the Davis-Bacon Act (40 U.S.C. \$\$ 276a to 276a7), the Copeland Act (40 U.S.C. $\$ 276 \mathrm{c}$ and 18 U.S.C. $\$ \$ 874)$, and the.Contract Work Hours and Safety Standards Act (40 U.S.C. \$\$ 327-333), regarding labor standards for federally assisted construction subagreements. 
10. Will comply, if applicable, with flood insurance purchase requirements of Section 102(a) of the Flood Disaster Protection Act of 1973 (P.L. 93-234) which requires recipients in a special flood hazard area to participate in the program and to purchase nood insurance if the total cost of insurable construction and acquisition is $\$ 10,000$ or more.

11. Will comply with environmental standards which may be prescribed pursuant to the following: (a) institution of environmerital quality control measures under the National Environmental Policy Act of 1969.(P.L. 91-190) and Executive Order (EO) 11514; (b) notification of violating facilities pursyant to EO 11738 ; (c) protection of wetlands pursuant to EO 11990, (d) evaluation of flood hazards in floodplains in accordance with EO 11988; (e) assurance of project consistency with the approved State management program developed under the Coastal Zone Management Act of 1972 (16 U.S.C. $\S \S 1451$ et seq.): (f) conformity of Federal actions to State (Clear Air) Implementation Plans under Section 176(c) of the Clear Air Act of 1955 , as amended (42 U.S.C. \$ 7401 et seq.); (g) protection of underground sources of drinking water under the Safe Drinking Water Act of 1974, as amended, (P.L. 93-523); and (h) protection of endangered species under the Endangered Species Act of 1973, as amended, (P.L. 93-205).

12. Will comply with the Wild and Scenic Rivers Act of 1968 (16 U.S.C. $\$ 1271$ et seq.) related to protecting components or potential components of the national wild and scenic rivers system.
13. Will assist the awarding agency in assuring compliance with Section 106 of the National Historic Preservation Act of 1966, as amended (16 U.S.C. 4701, EO 11593 (identification and protection of historic properties), and the Archaeological and Historic Preservation Act of 1974 (16 U.S.C. 469a-1 et seq.).

14. Will comply with P.L. 93-348 regarding the protection of human subjects involved in research, development, and related activities supported.by this award of assistance.

15. Will comply with the Laboratory Animal Welfare Act. of 1966 (P.L. 89-544, as amended, 7 U.S.C. 2131 et seq.) pertaining to the care, handling, and treatment of warm blooded animals held for. research, teaching, or other activities supported by this award of assistance.

16. Will comply with the Lead-Based Paint Poisoning Prevention Act (42 U.S.C. \$\$ 4801 . et seq.) which prohibits the use of leed based paint in construction or rehabilitation of residence structures.

i7. Will cause to be performed the required financial and compliance audits in accordance with the Single Audit Act of 1984.

18. Will comply with all applicable requirements of all other Federal laws, executive orders, regulations and policies governing this program.

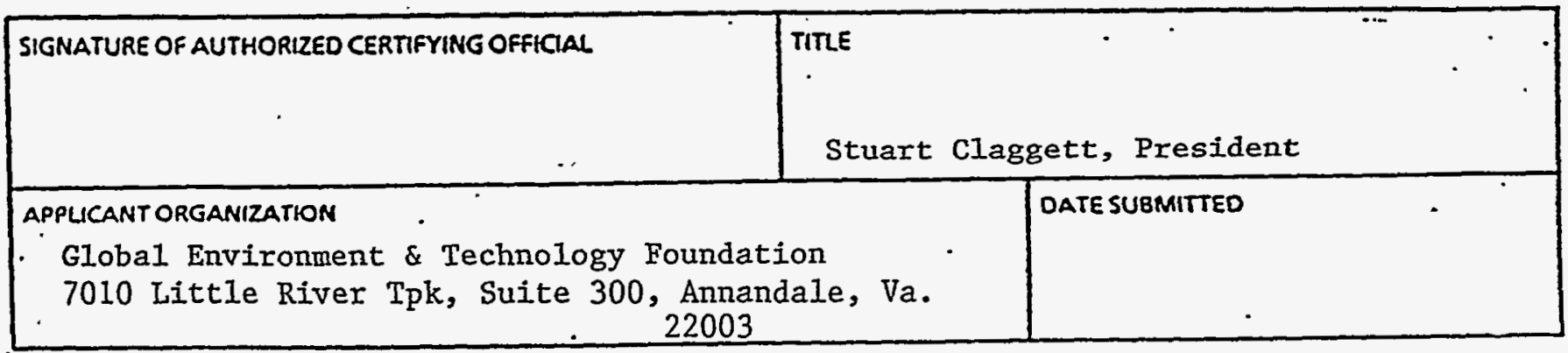




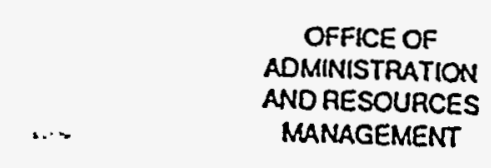

\section{Application Receipt Letter}

Mr. Stuart Claggett, President

Global Environment \& Technology Foundation

7010 Little River Turnpike, Suite 300

Annandale, Virginia 22003

Dear Mr. Claggett:

The U.S. Environmental Protection Agency's Grants Operations Branch has received your application. The EPA identification number assigned to your project is is this project's Grants Specialist. If you have any questions, please contact your grants specialist at (202) 564

Sincerely,

Barbara Rochon

Grants Administration Division 


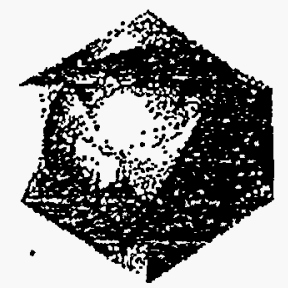

May 19. 1998

Ms. Laurie MeGilvray

MOAA

Office of Oceanic and Coastal Resource Management

1305 East-West Highway, Roam 10535

Silver Spring, Maryland 20910

Dear. Ms McGilvray:

Thank you for taking the time to talk wilh me regarding a potential partnership between the Cooperative Institute for Coastal and Estuarine Environmeatal Technology (CICEET) and the Global Envitonment \& Technology Foundation (GETF). I would like to arrange a meeting between GETF and CICBET to discuss possible collatroration opportunities.

As a new program, the CICEET will need early successes and the ability to communicate these successes to all of your stakeholders. GETF has already made the investments in information technology and networks that can provide the CICEET with these abilities and suppont your environmental technology mission responsibilities.

Allow me to provide you with a bit of background on GEIF. GETF, a 501(C)(3) not-fotprofit orgatization dedicated to the promotion and use of technology to achieve environmentally sustainable development, developed the Global Network for Environment \& Technology (GNET). Sponsored in part by the Global Environmental Technology Euterprise, an U.S. Deparment of Energy Federal Energy Technology Center initiative, GNET was created to support the commexcialization of innovative environmental technologies.

Since its establishment, the GNET systcm has been used by a number of federal programs to achieve collaboration and bring credibility to their efforts. GNET served as the on-line interactive communications service for the White House's Technology for a Sustainable Puture Initiative, bringing together high-level environmental decision-makers and facilitating development of the first national environmental technology strategy, "Bridge to a Sustainable Future." Vice President Al Gote cited GNET as the network for federal interameacy environmental technology collaboration and information-sharing activities. 
The CICEET can enhance its overall marketing strategy and receive substantive and technical input from GNET's team of webmasters, content, and information specialists. GNET can:

- Position the CICEET and the Infornation Depiction and Management System as a credible, proactive group dedicated the issue of cosstal and estuarine environmental technology research, development, and deployment.

- Build awareness of estuarine environmental technologies as a market with high potential.

- Establish CICEET as the leading source of education, information and policy recommendations on coastal and estuarine research and technology developnent.

- Promote the CICEET as the leading voice on Coastal and Estuarine Environmental Technology by building a robust Web community dedicated to these issues.

GNET features information on up-to-date news, procurements, and contracts in private sector, government, and technology development markets. Its market assessments deliver relevant information regarding the economic and policy drivers associated with moving a technology to market. GNET's user groups are based around the world. recording several million hits annually. 'This user base is growing at approximately $20 \%$ per montly with almost $51 \%$ being derived from small businesses.

GNET also provides federal agencies with Virtual Private Networks (VPNs) allowing comprehensive workgroup collaboration. VPNs are private, password-protected working environments that can be used by individuals to collaborate on a common project, whether they are across the hall or around the world. These VPNs," which we have developed for a number of agencies, allow the sharing of sensitive information and stakeholder collaboration through the use of advanced computer-based communications and information storage systems.

GETF proposes to meet with CICEET leadership to discuss partnerships and how we might support your goals and mission responsibilities. For example, GETF can support the construction of DEMS by adding the value of a network of environmental technology linkages and promoting greater access to the IDEMS system. Other options might include establishing a CICEET presence on globeNet - GNET's environmental inanagement services counterpart with expertise on ISO-14000 to ensure proactive strategies to address the environment imapacts of business practices. 
1 look forwand to discussing these issues in the near future. I have enclosed an information packet that provides more background on GETF and some of our projects. I will call you to arrange a mecting.

\section{Sincerely,}

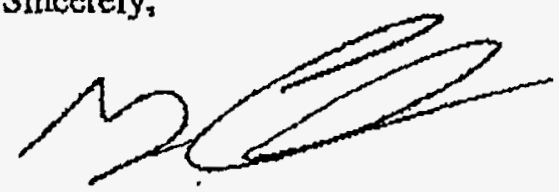

G.A. Chuck Chaitovitz

cc: Stuart Claggett, President

Enclosures. 
2 


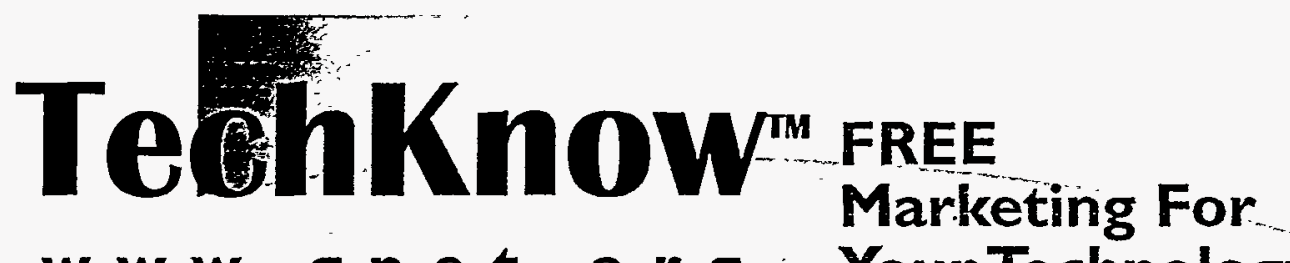 \\ w w w . g n e t.or g Your Technology \\ Enter your technology into TechKnoww and market right from your desktop.}

The Global Environment \& Technology Foundation (GETF) welcomes you to the WM ' 98 Waste Management Conference. GETF is a 50I(c)(3) not-for-profit corporation that fosters innovation by uniting the environment, technology and enterprise to encourage sustainable practices throughout the world.

\section{Resources}

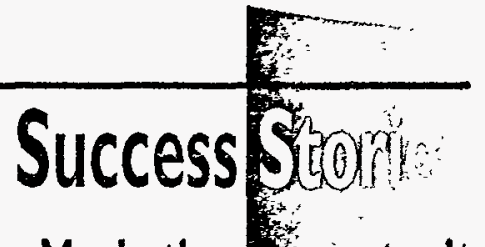

Free Marketing Epportunity - TechKnow

A featured Techknow technology (mobile, microwave vitrification) became a potential solution to a major fly ash problem. Follow-on discussions led to an immediate proposal submission! This is just one more opportunity that would not have happened without TechKnow.

International Exposure Sells Technology * AlE

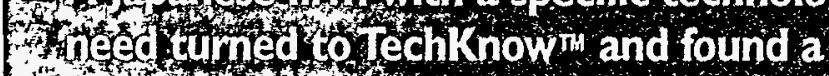

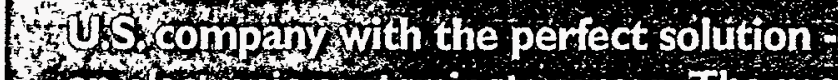
an ele ctronic contaminate sensor. The match resulted in the sale of two testing units and the option to buy 100 additional units.

Do you see ypur technology in the right manketplace?

Are you takingffull marketing advantage of TechKnow

\section{Global Network of Environment \& \\ Technology \\ An award-winning, on-line environmental business center highlighting TechKnow ${ }^{\text {ts }}$ a

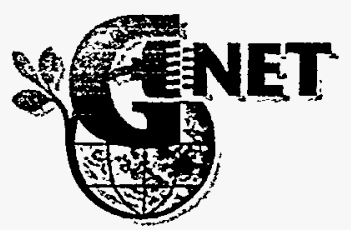
user based interactive environmental technology database that is easy to use and has a proven record for success.

\section{Deploying Environmental} Remediation Technology in the DOE Market

This brochure provides a starting point for technology developers who wish to introduce new and innovative environmental remediation technology to the U.S. Department of Energy (DOE).

\section{Do you need market information?} These industry sheets highlight DOE site technology needs.
1-Drum Management

2- Facility Characterization

3- Facility Decontamination

4- Asbestos Management

5- Subsurface Assessment

6- Remote Automated Systems and Tooling

7- Worker Protection Systems

8- Cutting \& Sizing, Demolition, and Disposition

9. Waste Treatment

10-Monitoring and Detection

I I- Mixed Waste

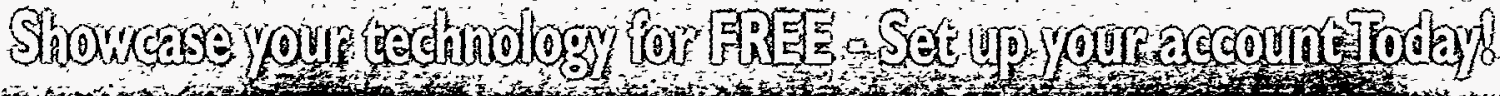
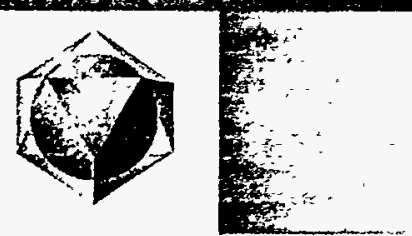

To find out more about GETF's programs and opportunities contact:

Global Environment \& Technology Foundation

7010 Little River Turnpike - Suite 300 - Annandale,VA 22003

Tel: 703-750-6401 • Fax: 703-750-6506 - www.getf.org

www.gnet.org $\bullet$ www.iso 14000 .net $-w w w . e a r t h v i s i o n . n e t$ 


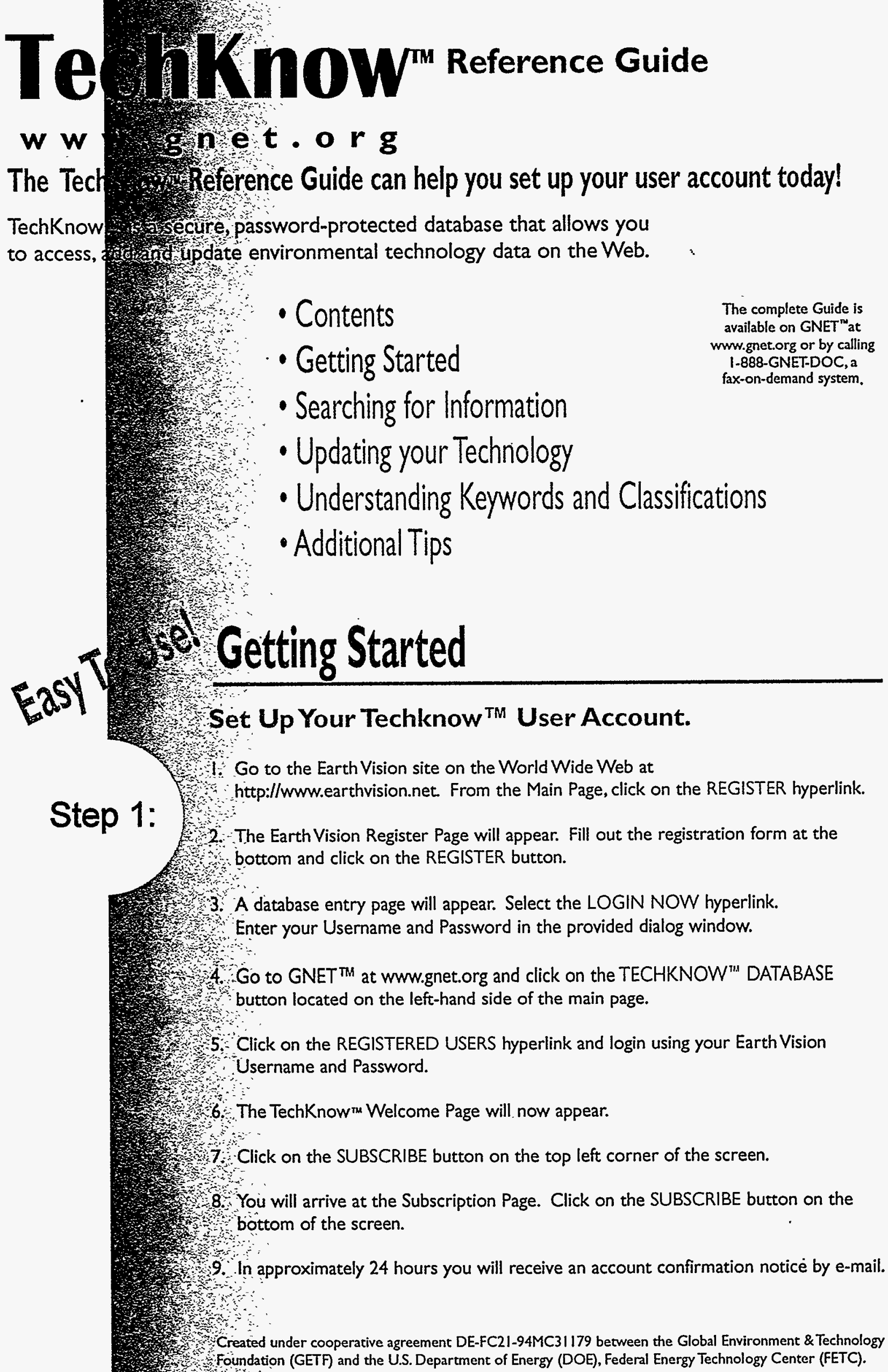

2. The Earth Vision Register Page will appear. Fill out the registration form at the bottom and click on the REGISTER button.

3. A database entry page will appear. Select the LOGIN NOW hyperlink. Enter your Username and Password in the provided dialog window.

4. Go to GNET ${ }^{\text {TM }}$ at www.gnet.org and click on the TECHKNOW ${ }^{\text {TI }}$ DATABASE button located on the left-hand side of the main page.

5. Click on the REGISTERED USERS hyperlink and login using your Earth Vision Username and Password.

6. The TechKnow Welcome Page will now appear.

7. Click on the SUBSCRIBE button on the top left corner of the screen.

8. You will arrive at the Subscription Page. Click on the SUBSCRIBE button on the bottom of the screen.

9. In approximately 24 hours you will receive an account confirmation notice by e-mail. 
uperiority through information management is crucial to being faster, better, and cheaper in today's marketplace. The Global Environment \& Technology Foundation (GETF) fosters innovation by using information technology to solve environmental problems worldwide. GETF has created several Virtual Private Networks (VPNs) adding value and productivity to both the private and federal sectors. A VPN is a virtual workspace on the World Wide Web that will allow selected individuals and groups to leverage the knowledge capital of a specific project/program. Using interactive tools, a VPN captures critical information and can help improve the overall project/program process.

With a secure authentication and authorization process, members will be assigned specific levels of access within the VPN. The system will permit quick, controlled access of working documents and position papers, and allowing interaction and coordination using the information architecture of the World Wide Web. The following are some of the capabilities that can be integrated within a VPN:

\section{Content Population:}

Documents, files, hyperlinks, pictures, publications and any other content can be posted to the VPN for all members to review.

- Pertinent news abstracts

- Links to related Web sites

- Supporting resources

\section{Reference Areas:}

Provides an area for final versions of proposals, policies, agendas, and documents to be posted.

- Provides reference material which is crucial for developing future actions

- Documents can be viewed on-screen or downloaded in multiple file formats

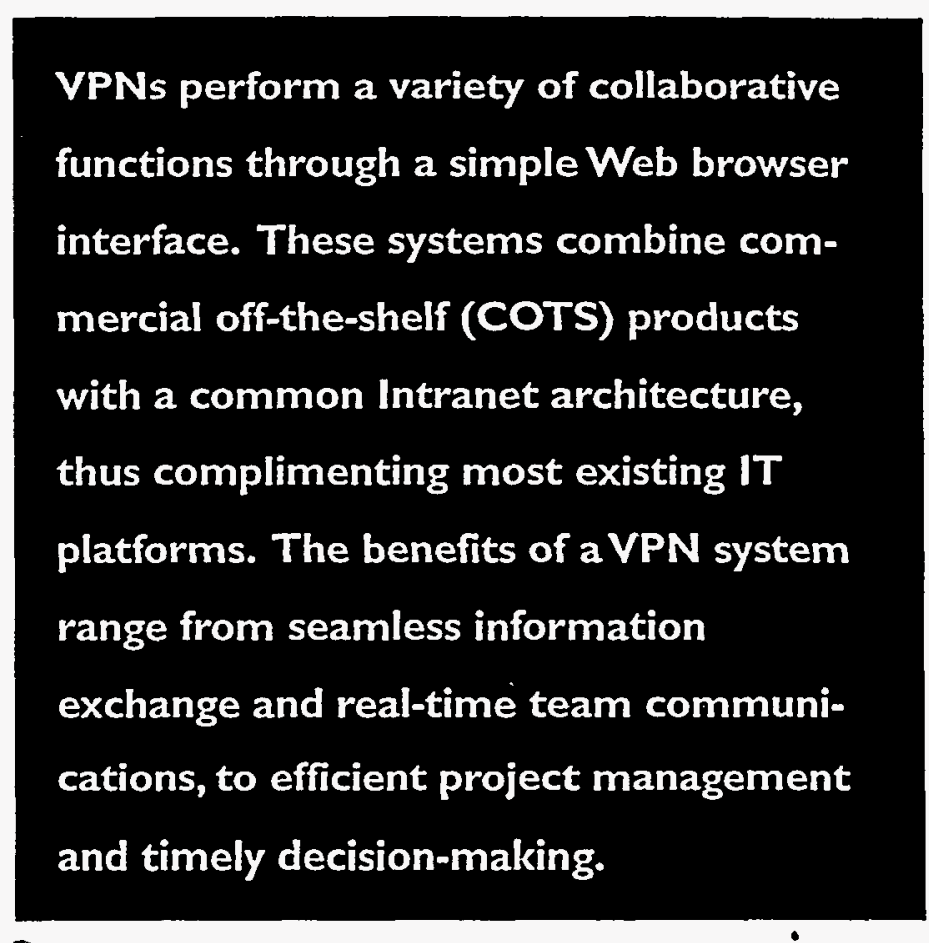

\section{File Libraries:}

The File Libraries provide an area where working documents and other electronic files can be posted, indexed and referenced quickly and easily through the library functions.

- Able to upload and download multiple file formats Ensures the latest versions of documents are available to members

- Provides historical archive for documents

Used to develop proposals, policies and draft documents

\section{Real-Time Chat:}

Provides an area for members to conduct real-time meetings, discussions and opinions via the Internet.

- Unlimited chat room capacity

- Provides screening and moderating of chat discussions

- Provides detailed transcript of chat events 


\section{Conference Areas:}

These advanced "message board" areas allow members the ability to post a message, respond, search and track conference dialogue.

- Allows members to post questions/opinions on issues not yet contained in reference area

- All file formats can be saved as attachments

- Multiple sorting functions

\section{Member Directory:}

An on-line member directory that lists contact information and links to each member's e-mail account.

- Easily updated

- Provides multiple avenues for communication

\section{E-mail Integration:}

Provides capability to send a message to all members of a designated group.

- Can establish traditional listserv capabilities

- Can be correlated with conference areas and file libraries

\section{Network Search:}

This feature allows the user to search for any materials posted to the site across all areas of the VPN.

- HTML and other files

- Messages from conferences, file libraries and reference materials

- Database records

- Chat transcripts

\section{Calendar of Events:}

Provides an area for posting upcoming conferences, meetings and other events.

- Provides chronology of upcoming events

- Provides a short description of upcoming events

- Event listings can be added/updated by members

On-line user's manual and training can be provided to individuals or groups.

\section{For more information on Virtual Private Network Services, contact:}

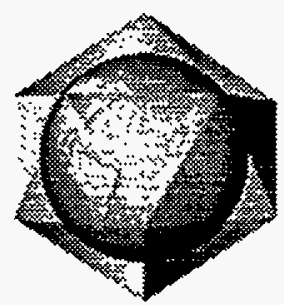

\section{Global Environment \& Technology Foundation}

7010 Little River Turnpike - Suite 300

Annandale,VA 22003

Tel: 703-750-6401 - Fax: 703-750-6506

Email: getf@getf.org 

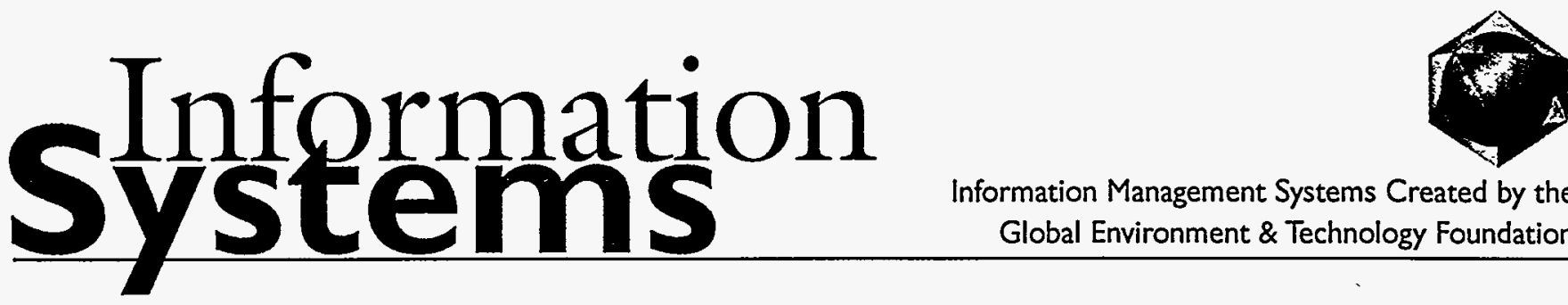

Information Management Systems Created by the Global Environment \& Technology Foundation

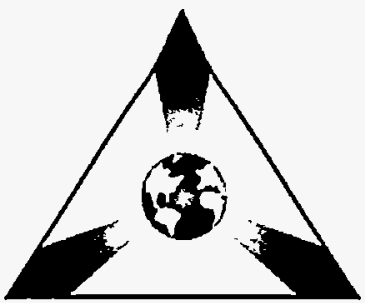

EARTHVISION

\section{WWw.earthvision.net}

Earth Vision is a worldwide environmental community that brings together organizations, businesses and individuals to collaborate and serve as an international forum on the Web. Earth Vision's five "neighborhoods" include business and technology, education, policy and advocacy, recreation, and sustainability. There is no cost to visit or join Earth Vision.

Stakeholders include:

Non-profit organizations, companies, academia and individuals worldwide
$\mathrm{GNET}^{\mathrm{TM}}$ provides timely information to all stakeholders on environmental topics.

Stakeholders include:

Domestic and International

- Businesses

- Governments

- Academics

- NGOs

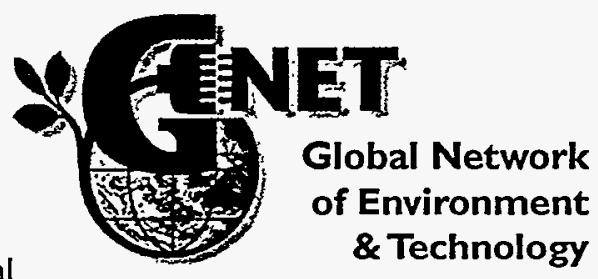

www.gnet.org

\section{TechKnow}

is an interactive environmental

technology database residing on GNET TM

that allows users to search for timely

information, as well as add and update

their information in a password-protected

environment. Techknow ${ }^{\text {TM }}$ creates a

virtual Web site for your technology

free of charge.

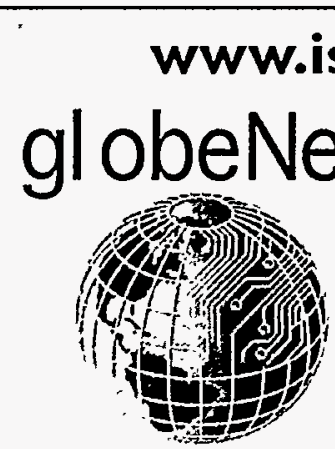

Stakeholders include:

Domestic and international organizations manufacturing products or offering services

\section{globeNet ${ }^{\mathrm{TM}}$ \\ Provides up-to-date, relevant information and discussion facilitation of environmental management systems on the Web.}

Brownfield Network - Under development for the EPA, the Brownfield Network is a private network that allows federal agencies to share and process policies and guidelines.

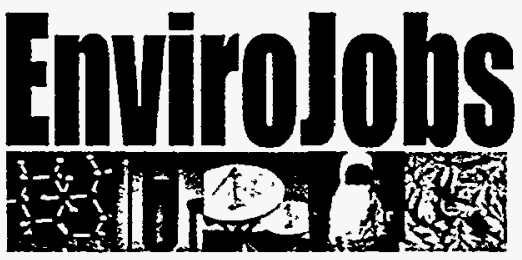

www.earthvision.net/envirojobs

Envirojobs is an innovative program designed to fulfill the need to train and certify unemployed and underemployed workers utilizing environmental technologies to meet the challenges of sustainable development.

Stakeholders include:

Industry, public/private organizations, academia

Stakeholders include: Federal agencies with potential expansion to other stakeholders (e.g., states, NGOs, industries) 


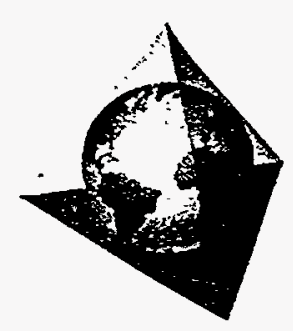

WeNet - World Engineering Network

Developed for the World Engineering Partnership for Sustainable Development

(WEPSD), WeNet allows decision makers on a global basis to share information, create relationships, promote global ethics and advance leadership.

Stakeholders include: International governments, industry and professional associations WWW.Wenet.org

RCI - The Rapid Commercialization Initiative is a cooperative effort between federal agencies and states to provide internal communications on testing, methodology, data and public dissemination.

\section{Stakeholders include: Technology demonstrators, federal agencies and states}

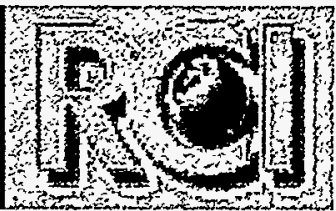

rci.gnet.org

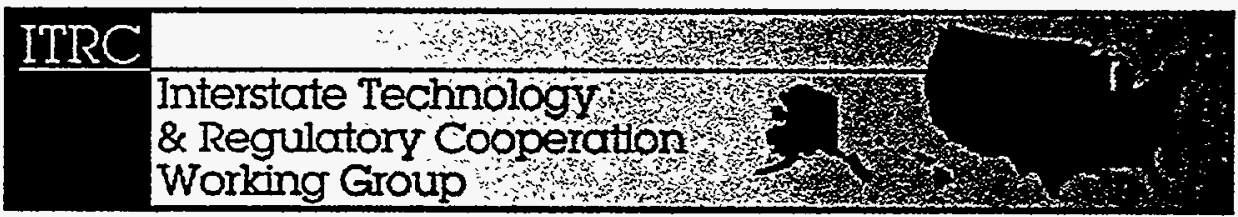

ITRC - The Interstate Technology and Regulatory Cooperation Working Group provides internal communication among members, as well as outreach to interested environmental communities.

Stakeholders include: 26 participating states and federal agency advisors

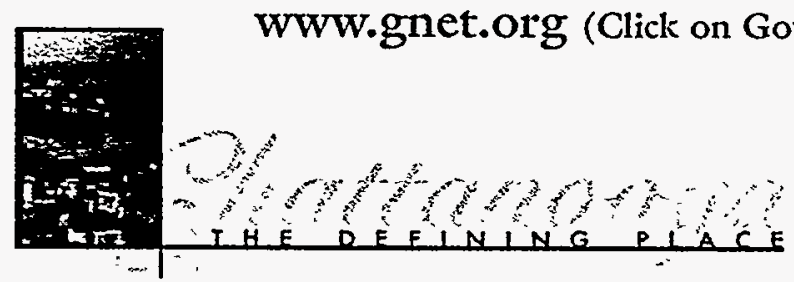

The Chattanooga Intranet provides community-wide coordination and collaboration on the City's strategy for revitalization.

Stakeholders include: River Valley Partners, entire Chattanooga community, public and private community leadership

The Environmental Technology Initiative (ETI)

Database is an internal project management tool developed for the Environmental Protection Agency (EPA), public dissemination and project coordination.

Stakeholders include: EPA, project partners, interested communities, other federal agencies and states

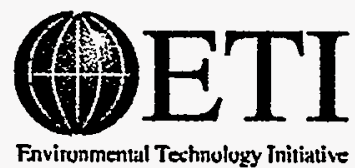

www.gnet.org/eti

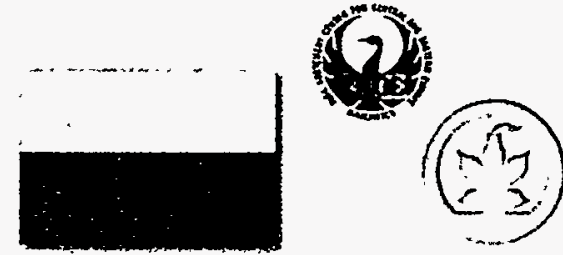

Central and East European Information Center (CEEIC) is a model system created for the Risk Abatement Center in Katowice, Poland to disseminate information and technologies.

Stakeholders include: International community

http://ietu.ceeic.org 


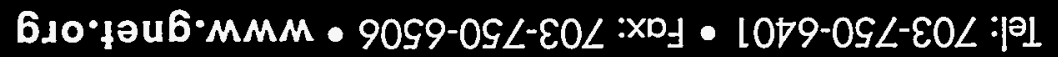

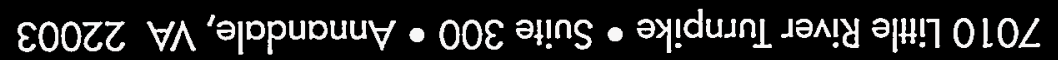

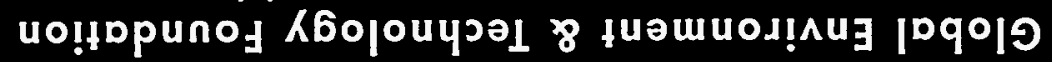

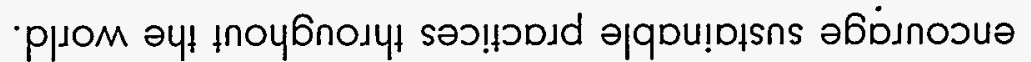

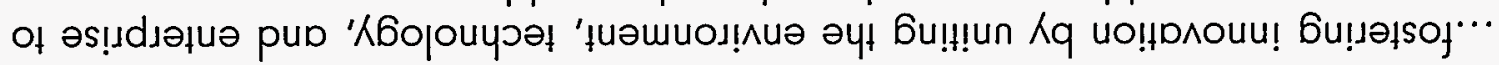

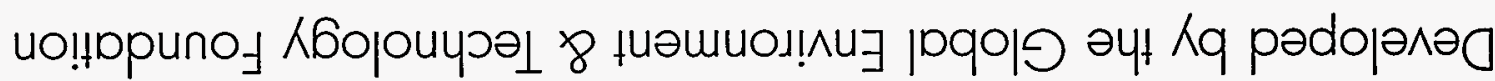

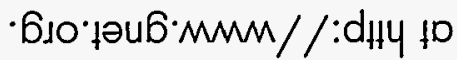

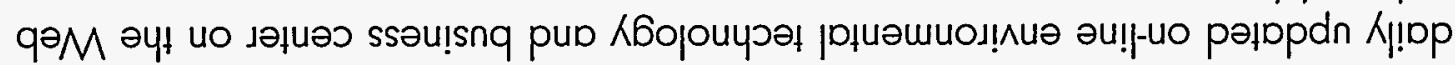

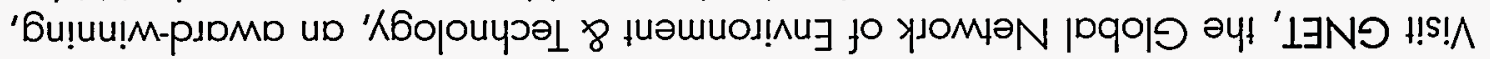

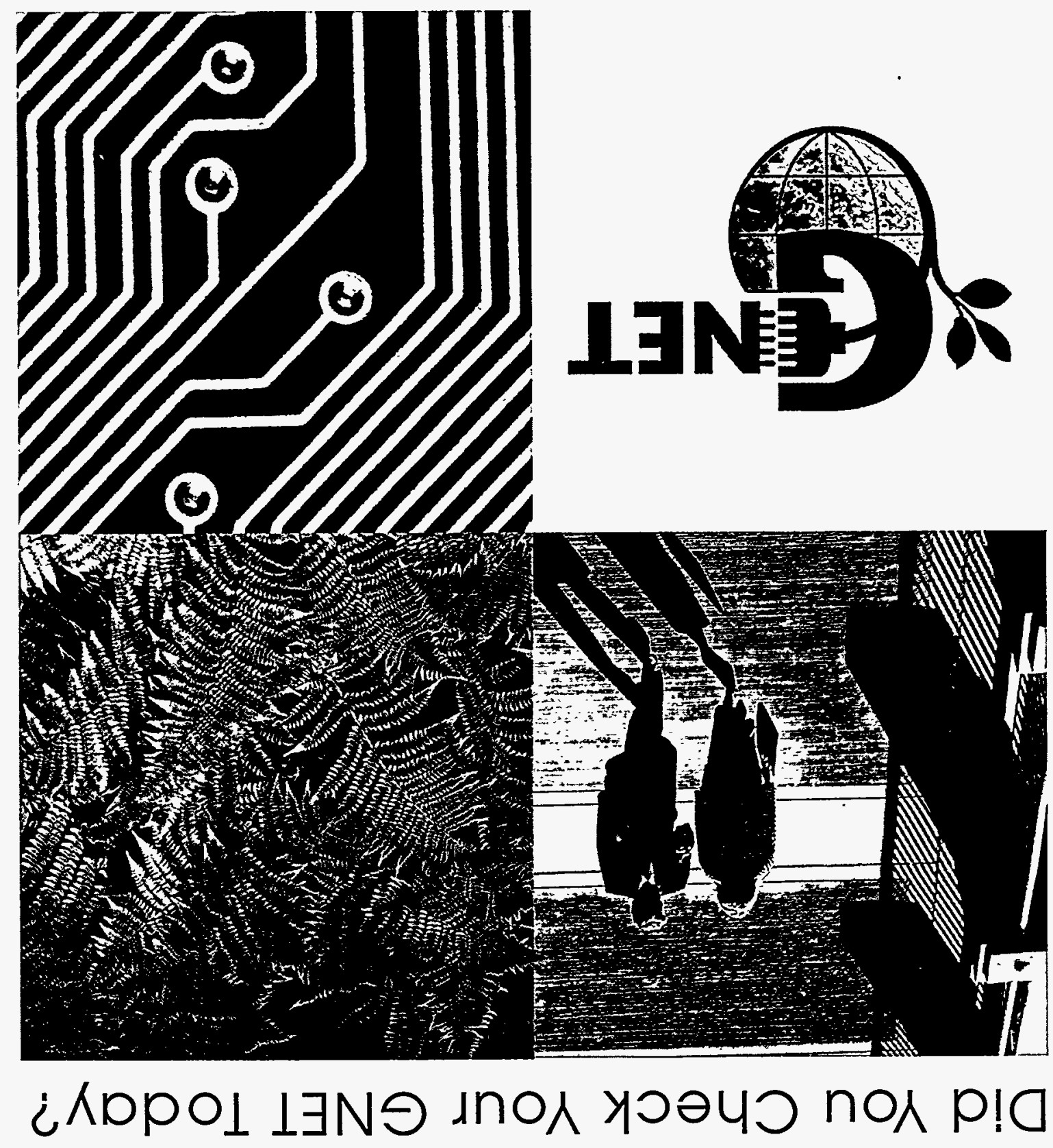




\section{Need to solve your toxic problems? Want your technology on the Web?}

Welcome to the...

\section{TechKnow \\ darabase}

You're in a competitive business environment and can't afford to waste time looking for information. You want to aggressively market your innovative technology. You can with TechKnowrm.

TechKnowrm allows you to add and update your own technology developments right from your desktop! TechKnow'm offers a targeted search capability by combining multiple category

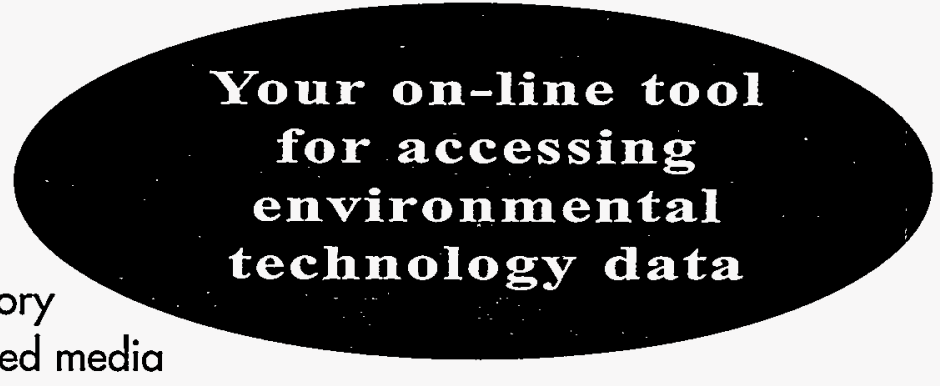
schemes, including contaminant groups, affected media and other keywords. It provides a wealth of reliable, accurate and high-quality environmental technology information in one comprehensive database.

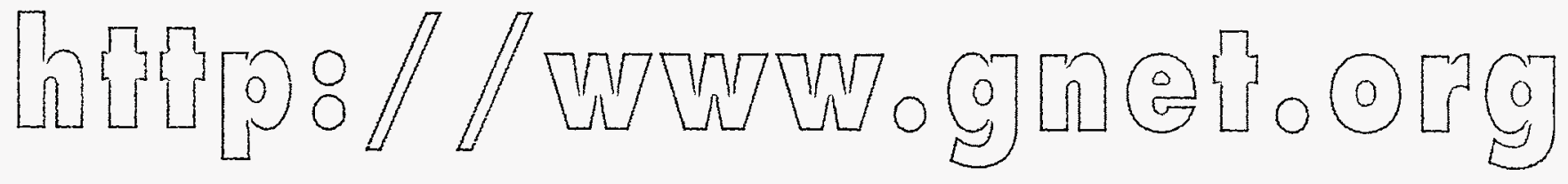

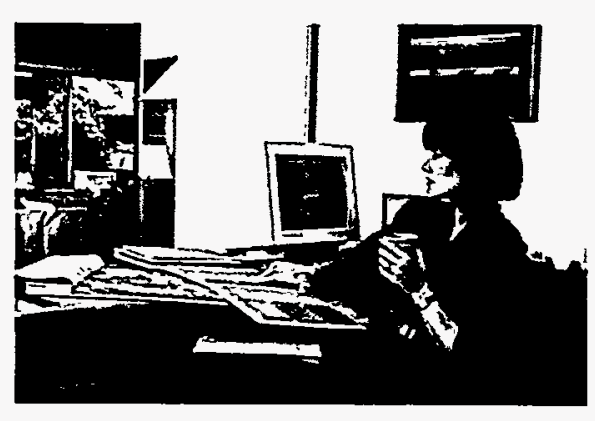

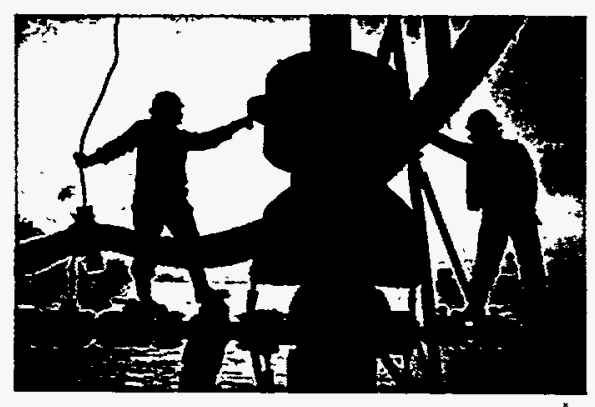

\section{TechKnow has it!}

User-owned technology profiles

Multiple search criteria

Summaries and full descriptions

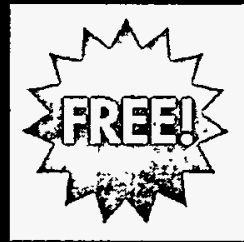

- Related information from DOE and other sources

- Demonstration, intellectual property and licensing status

Technology needs, limitations, applications and costs

Technology developer contact information I 
3 


\section{Deploying}

Environmental

Remediation

Technology

in the DOE Market

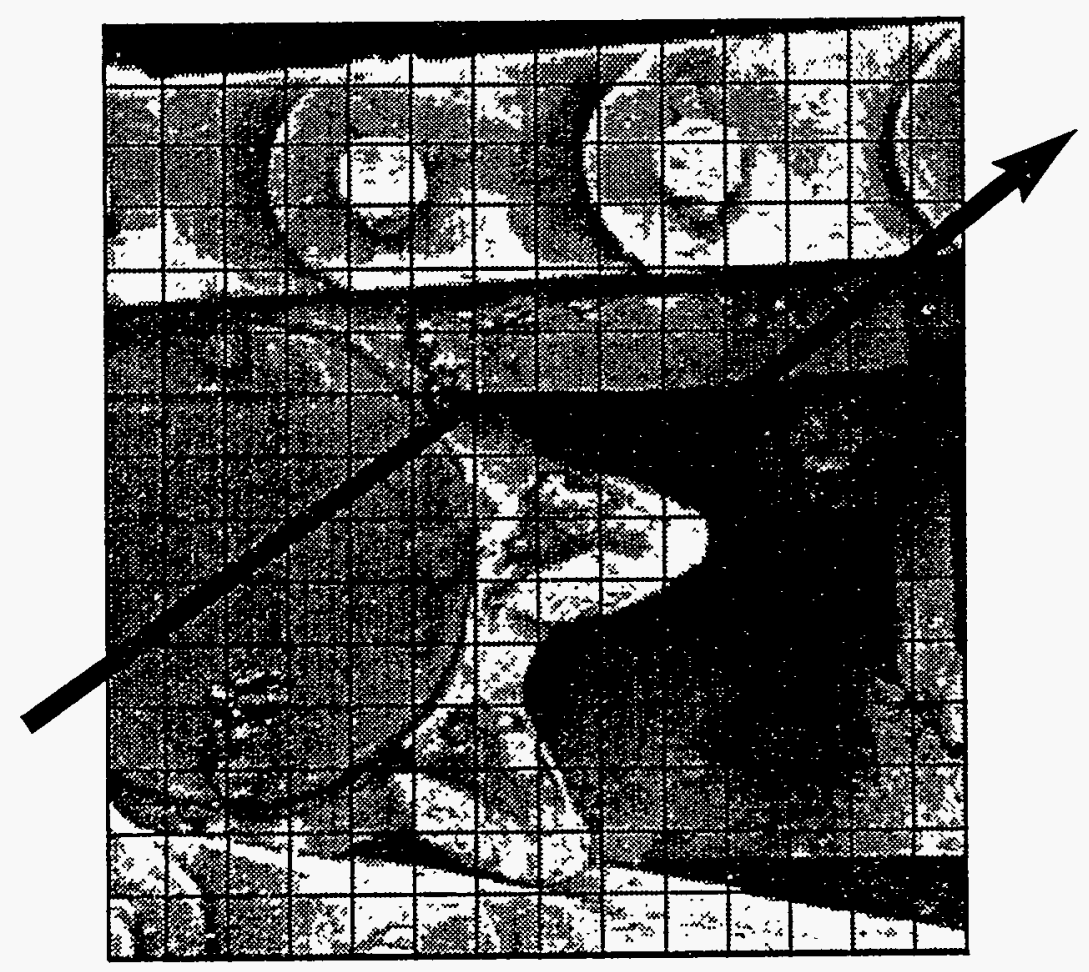

Revised - May 18, 1998 


\section{Deploying \\ Environmental \\ Remediation \\ Technology \\ in the DOE Market}

This brochure provides a starting point for technology developers who wish to introduce new and innovative environmental remediation technology to the U.S.

Department of Energy (DOE). While not all inclusive, the information provided will assist in placing these technologies on the path to deployment at DOE facilities and speed site environmental remediation.

\begin{tabular}{|ll}
\hline Page I & The DOE Market \\
\hline Page 3 & Site Locations and Budgets \\
\hline & DOETechnology Needs \\
\hline Page 4 & Facts and Challenges \\
\hline Page 6 & Information Resources \\
\hline & Targeted Web Sites \\
\hline Page 8 & Marketing \& Sales to DOE \\
\hline
\end{tabular}


The DOE budget request for fiscal year 1998 is extensive. The expecred appropriation will be about $\$ 7.6$ billion dollars. Of that, more than $59 \%$ is earmarked for environmental remediation and waste management $(\$ 4.5$ billion dollars). A market this large is difficult for even small companies to ignore. The following charts show the locations and budgets of the major DOE sites. This information will assist regional and smaller companies target their marketing resources.

\section{Major DOE Site Locations}

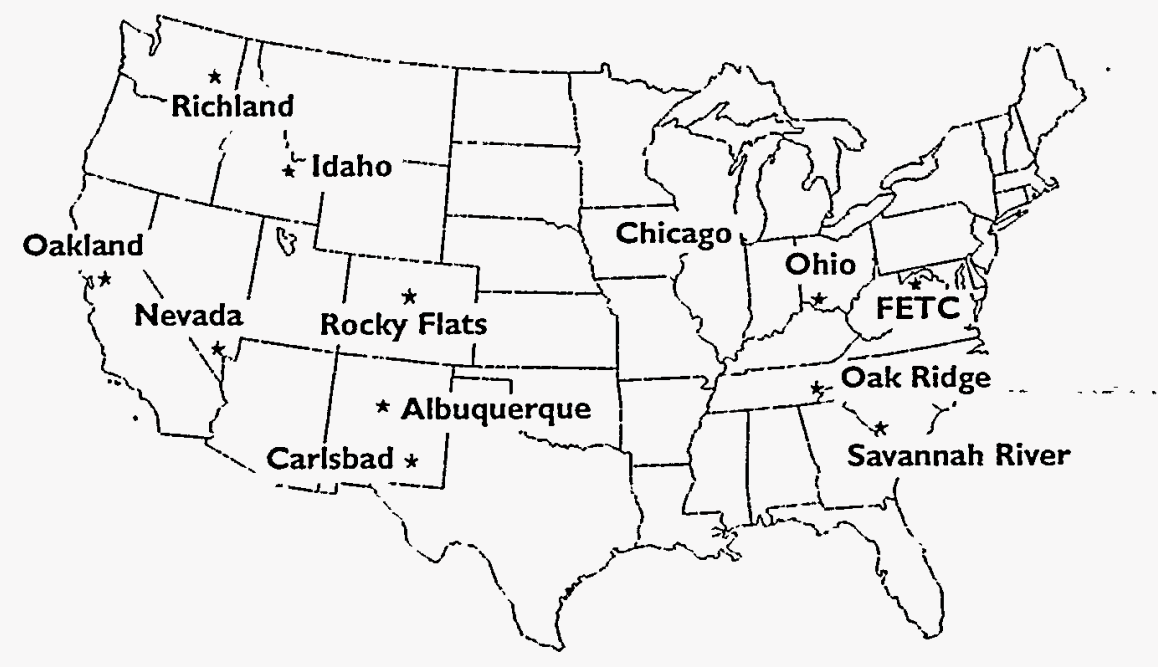




\section{DOE - Environmental Management FY 1998 Appropriations \\ (Dollars in Millions)}

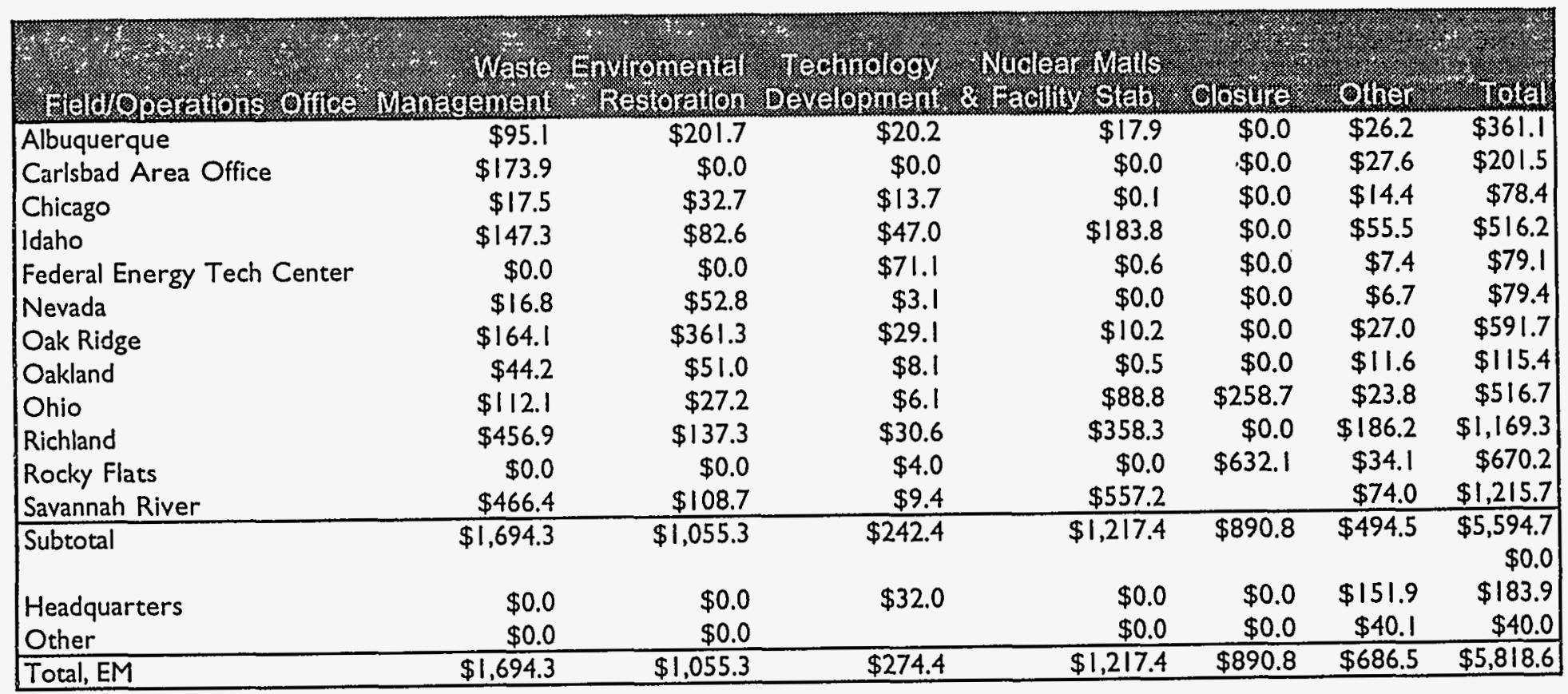


As a result of the legacy of the cold war, DOE has unique and complex environmental remediation needs. At many sites, DOE is faced with large surface and subsurface areas contaminated with hazardous and radioactive materials. Further, past waste management practices such as the direct burial of drums containing mixed hazardous and radioactive waste, are no longer acceptable and must be addressed as part of the cleanup program. Penetration of the DOE market is often impacted by budget uncertainties, shifting implementation strategies, site management and contracting mechanisms. However, the mandate for cleanup is here today, and the emphasis on rapid cleanup is expected to grow.

\section{FACT: The DOE environmental remediation market is extremely large.}

- 200 million cubic meters of contaminated soil

- 5,700 underground plumes needing remediation

- 3,000 contaminated buildings

\section{Technology Introduction}

Every technology developer attempting to introduce a new technology must:

1. Specifically identify the problem at an individual site where the technology may be of benefit.

2. Clearly demonstrate to the weapons complex site decision makers that the technology is:

- Safer (reduces risk),

- Faster (saves time), and

- Cheaper (saves money)

than the baseline technology being used or planned for use by the site. 
As a result of the expansion of the Internet, a great deal of information abour DOE needs and opportunities for innovative technological solutions is located on the World Wide Web (WWW). The following WWW sites will give the technology developer some ideas concerning which specific DOE sites have problems that can be addressed by a particular technology.

\section{Targeted Web Sites}

- National Accelerating Cleanup: Focus on 2006 http://www.em.doe.gov/closure

This site contains discussion drafts of the National DOE accelerated environmental remediation plan, described site by site.

\section{- Environmental Restoration Program Requirements http://www.em.doe.gov/define}

This site, although complicated to use, outlines a process for the DOE Office of Environmental Restoration (EM-40) to bring innovation and competition to the remediation process.

- Site Technology Coordinating Groups (STCGs) http://em-52.em.doe.gov/ifd/stcg/needs.htm

This location lists technology needs expressed for each DOE site. These needs have been updated several times in the past year. 


\section{Sites with specialty areas of concentration include:}

- Subsurface Contaminants Focus Area site http://em-52.em.doe.gov/ifd/scfa/scfa.htm

- Idaho National Engineering and Environmental Laboratory's Mixed Waste Focus Area site http://wastenot.inel.gov/mwfal

- Federal Energy Technology Center's Decontamination \& Decommissioning (D\&D) Focus Area site http://www.wpi.org/doe/focus/dd/

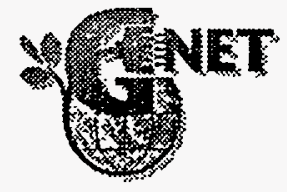

- All of these sites may be accessed chrough $G N E T^{\mathrm{ms}}$ Global Network of Environment \& Technology. http://www.gnet.org

GNET $^{\text {TM }}$ is a major resource for technology developers and environmental technology stakeholders. Also available on GNET $^{\text {TM }}$ are eleven mini DOE market studies.

Market Study Topics Include:

- Monitoring and Detection

- Subsurface Assessment

- Waste Treatment

- Drum Management

- Remote Automated Systems \& Tooling

- Facility Characterization

- Facility Decontamination (process and equipment)

- Cutting \& Sizing, Demolition and Disposition

- Asbestos Management

- Worker Protection Systems

- Mixed Waste 
Marketing and sales to DOE can be frustrating but there are some ways that a technology developer can better the chances of success. Those who are successful will develop a multi-step process which starts with long-term strategy and planning. Opportunities, uncovered by research, must constantly be assessed and much ground work accomplished well before formal opportunities are announced. Because of the complexity of the DOE market, success means having experienced personnel on the technology development team. Time must be spent at the site most suited for your technology, meeting with those on the scene so that they will get to know you and your products.

By itself, DOE does not buy technologies, goods or services. The National Laboratories, site contractors and sub-contractors do.

\title{
National Laboratories
}

National Laboratories are operated by both for-profit and notfor-profit contractors. Traditionally for-profit contractors are easier to market to because they have the financial incentives to be more cost effective.

\author{
Not-for-Profit Laboratories Include: \\ Lawrence Berkeley Laboratory \\ Los Alamos National Laboratory \\ Pacific Northwest Laboratory \\ Lawrence Livermore National Laboratory \\ Argonne National Laboratory \\ Brookhaven National Laboratory
}

For-Profit Laboratories and Associated Companies Include: Sandia National Laboratory - Lockheed Martin Idaho National Engineering and Environmental Laboratory Lockheed Martin

Oak Ridge National Laboratory (X-10) - Lockheed Martin 


\section{DOE Contractors}

The following is a list of contractors who manage the DOE sites. They are divided into two categories. One category includes Management \& Operating $(\mathrm{M} \& \mathrm{O})$ contractors. M\&O's tend to perform remediation work with their own personnel. They are more likely to buy hardware rather than services. The other category includes Management \& Integrating (M\&I) contractors. M\&I's tend to contract work to second and lower-tier subcontractors. If you are a service provider, M\&I's probably offer more opportunities for sales. The recent trend in DOE is moving toward M\&I contracts.

\section{M\&O Contractors:}

Nevada Test Site - Bechtel

Oak Ridge (Y-12) - Lockheed Martin

\section{M\&l Contractors:}

Fernald - Fluor Daniel

Hanford - Bechtel Hanford

Hanford - Fluor Daniel

Kansas City Plant - Allied Signal

Mound - Babcox and Wilcox

Oak Ridge (K-25) - Bechtel Jacobs

Pantex - Fluor Daniels

Pinellas - Lockheed Martin

Portsmouth - Bechrel Jacobs

Paducah - Bechtel Jacobs

Rocky Flats - Kaiser-Hill

Savannah River Site - Westinghouse

There are several ways to inform DOE and $M \& O / M \& I$ contractors about your technology. One is to register it on the TechKnow ${ }^{r m}$ database. TechKnow ${ }^{r M}$ is locared on GNET ${ }^{\text {M }}$ at http://www.gnet.org. This free service will ensure that your technology is available for review by interested problem holders. Another way is to submit a cost and performance report to DOE. This report is designed to comprehensively document the performance and cost of successful applications of new and innovative technologies. This information is used by decision makers as they consider technologies for use. Although prepared by the rechnology vendor, the report must be signed off by a user and regulator. The format is specified in Documenting Cost and Performance for Environmental Remediation Projects which can be found at http://www.em.doe.gov/define. 
This list will be periodically updated.

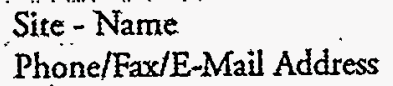

DOE HQ Champion - Michael Barainca

301-903-7259/301-903-7618/michael.barainca@em.doe.gov

Albuquerque - Karen Douglas

505-845-6411/505-845-4883/kdouglas@doeal.gov

Chicago - Jim Paulson

630-252-2770/630-252-2654/james.paulson@ch.doe.gov

Fernald - Rod Warner

513-648-3156/513-648-3076/rod.warner@fernald.gov

Idaho - Warren E. Bergholz

208-526-2497/208-526-5406/berghowe@inel.gov

Nevada - Frank DiSanza

702-295-5855/702-295-1810/disanza@nv.doe.gov

Oak Ridge - Carolyn Davis

423-576-0418/423-576-5333/daviscm@oro.doe.gov

Oakland - Elisabeth Reber-Cox

510-637-1713/510-637-2001/elisabeth.reber@oak.doe.gov 


\author{
Ohio - Doug Maynor \\ 937-865-3986/937-865-4402/doug.maynor@em.doe.gov \\ Richland - Shannon Saget \\ 509-372-4029/509-372-4549/shannon_n_saget@rl.gov \\ Rocky Flats - Gary Huffman \\ 303-966-7490/303-966-6713/gary.huffman@rfets.gov \\ Savannah River - Sharon Robinson \\ 803-725-5793/803-725-3616/sharon.robinson@srs.gov
}

\title{
Major DOE Site Locations
}

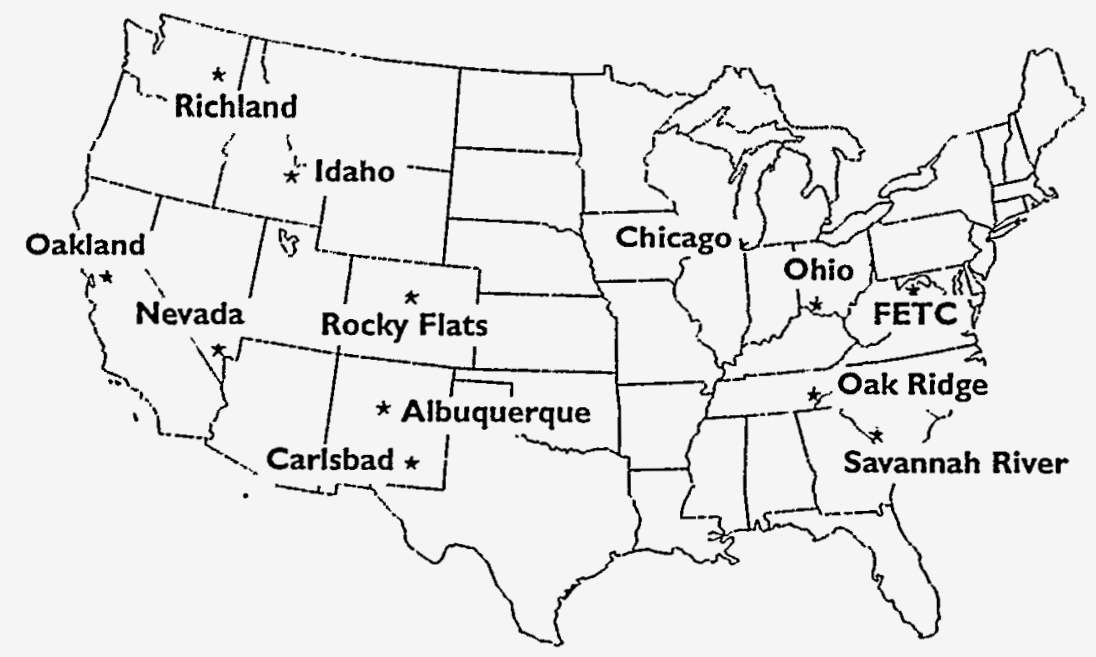




\section{Deployment Resource Guide}

Another resource available to technology vendors is the Global Environmental Technology Enterprise, GETE Technology Deployment Resource Guide. The resource guide is a compilation of tools and information on a wide variety of subjects relating to technology deployment at DOE. Included are sections on barriers, regulations and the elements of writing a deployment plan. For further information please contact us at gete@getf.org or (703) 750-6401. This information will be available soon on the GNETTM Web site at http://www.gnet.org.

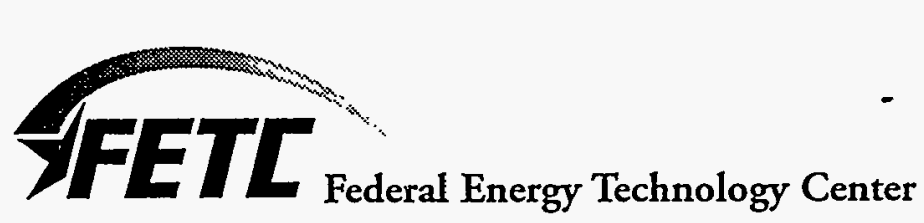

3610 Collins Ferry Road

Morgantown, WV 26507-0880

Tel: 304-285-4229

http://www.fetc.doe.gov

Created under cooperative agreement DE-FC21-94MC31179

between the Global Environment \& Technology Foundation (GETP) and the U.S. Department of Energy (DOE), Federal Energy

Technology Center (FETC). 


\section{TechKnow $^{\mathrm{TM}}$ Reference Guide}
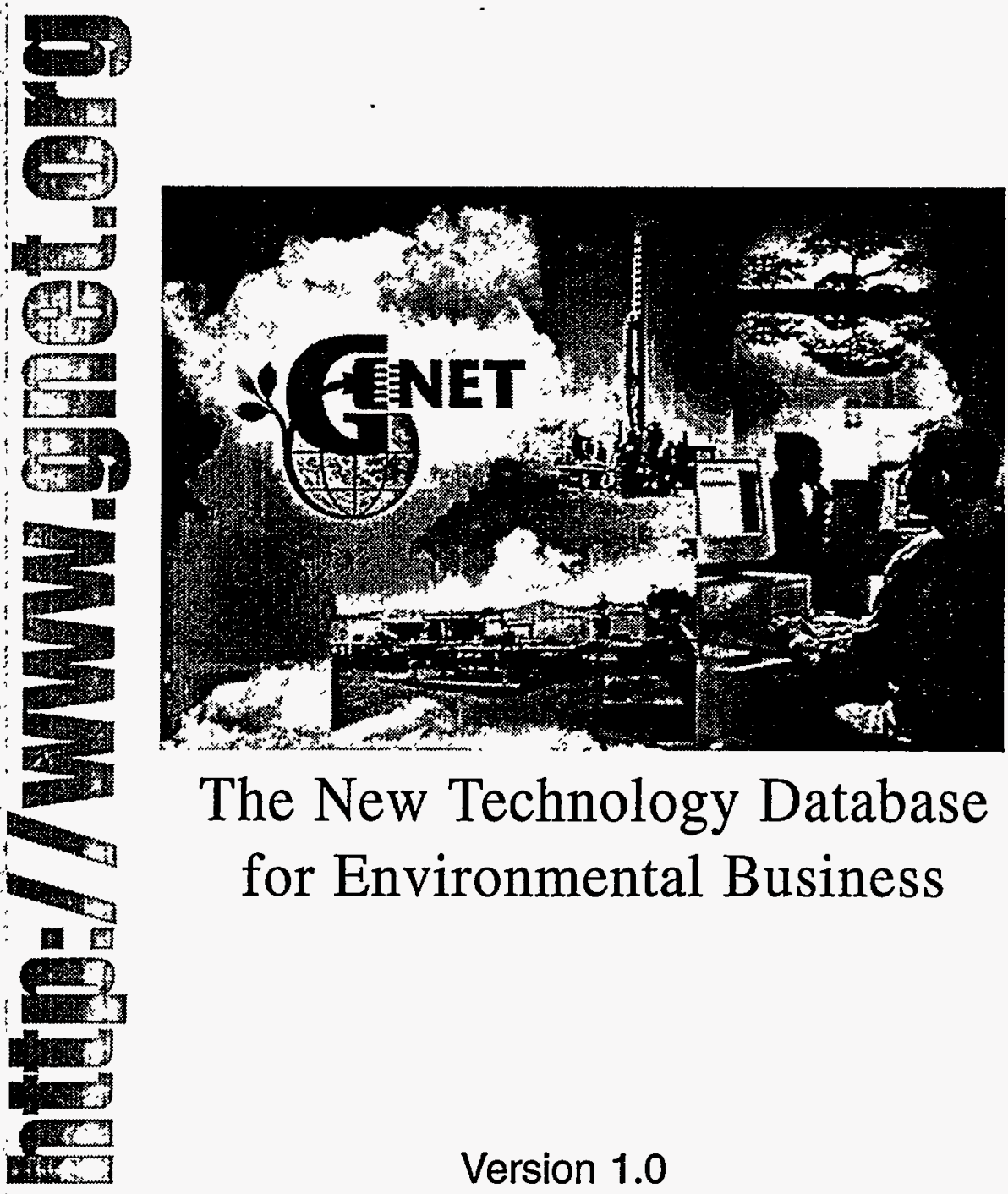

The New Technology Database for Environmental Business

Version 1.0 


\section{Background}

\section{What is TechKnowm?}

TechKnow is not just a database on the World Wide Web. It is a free, easy-to-use tool that can help you learn more or share more - about innovative environmental technologies.

A secure, password-protected database, TechKnow allows . you to access, add, and update data highlighting environmental technologies over the Web.

All you need to enter TechKnow is a personal computer, access to the World Wide Web, and a frame-compatible Web browser (Netscape ${ }^{\mathrm{s}}$ or Microsoft Explorer ${ }^{\mathrm{T}}$ version 3.0 or higher). In order to use TechKnow ${ }^{m}$, you must register and open a free user account.

This reference booklet provides step-by-step instructions to help you use TechKnown.

\section{ABOUT TEBHKNOW'M}

Access TechKnow" at www.gnet.org, and click the "About TechKnow" button!

GNETw and TechKnow ${ }^{\text {nu }}$ are a part of the Global Environmental Technology Enterprise (GETE), an initiative managed by the Global Environment \& Technology Foundation and supported, in part, by the U.S. Department of Energy and the Federal Energy Technology Center, under cooperative agreement DE-FC21-94MC31179. 


\section{TechKnow ${ }^{\text {TW }}$ Reference Guide Contents}

\section{Getting Started}

2

Searching for Information

4

\section{Updating Your Technology}

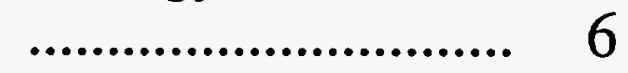

\section{Understanding} Keywords and Classifications

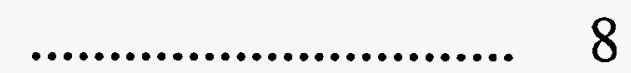

Additional Tips

9 


\section{Getting Started}

Step 1: Set Up Your TechKnow ${ }^{T M}$ User Account.

1. Go to GNET ${ }^{\mathrm{m} M}$ on the World Wide Web at http://www.gnet.org. From this Main Page, click on the "Technology Center", then click on the TECHKHOH' DATABASE button.

2. The TechKnow ${ }^{\text {TM }}$ Main Page will appear. Click on the REGisien button.

3. A database entry page will appear. Click on EHTER IECH (KOY'M' button.

4. A window will appear asking you to log in. Type in "techuser" and "guest"*, then hit enter.

5. TechKnow ${ }^{\text {TM }}$ will now appear (it produces frames on your screen).

6. In the top, left-hand corner click on the green REEISIER button. Fill in all fields (you create your own UserID and Password). Keep in mind these fields are case-sensitive.

7. You should receive a confirmation message stating whether your account is approved within $24 \mathrm{hrs}$.

*The guest UserID and Password may only be used to "View" technology information.

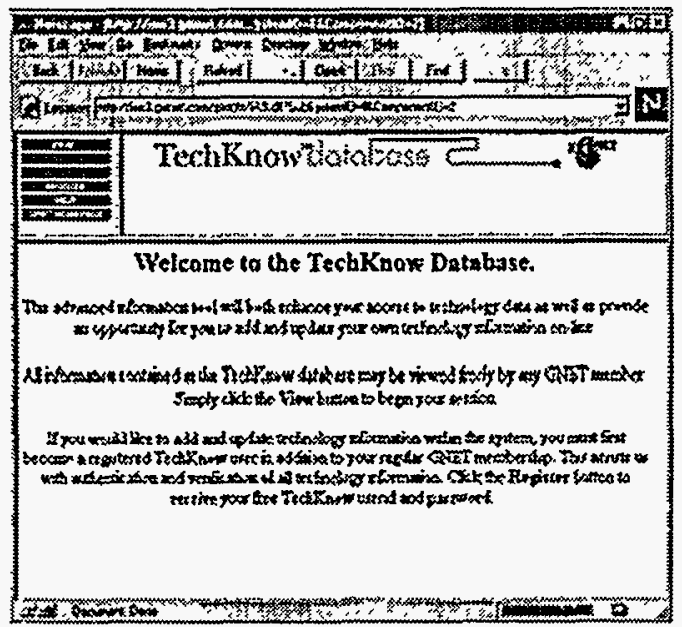


Step 2: Check to See if Your Technology is Already Listed.

1. While inside the system, click on the green VIEW' button. Eight buttons will appear at the top of your screen.

2. Click on the purple HAME button. The alphabet will appear on the left side of your screen. You may either click on the letter that your technology begins with, or click on "Display All" to browse for your technology.

3. If you find your technology in the system, click on it to view the full profile. Check the "Editor" field (on the right side, third from the top) to see who currently owns the profile.

4. Each technology profile in the system is linked to one TechKnow ${ }^{\mathrm{TM}}$ account. If you are unfamiliar with the "Editor" you will need to send us a request via e-mail to gnet@getf.org so we can assign the profile to you. The profile must be assigned to your account before it can be updated.

\section{$A D D$}

Add Your Technology to TechKnow ${ }^{\text {TM. }}$.

1. After your account has been approved, go to TechKnow ${ }^{\mathrm{TM}}$ and $\mathrm{log}$ in with your UserID and Password (Required).

2. Once inside, click on the green ADO/OPDAIE/DEIEIE button in the top, left corner. Three buttons will appear at the top of your screen.

3. Click on the purple ADD button. Eight buttons will appear on the left side of your screen.

4. Click on the purple GEHERAL IHFO button to begin creating your profile. Fill in all applicable fields. When finished, click the SAVE button.

5. Once you are satisfied with the information, click the green SEFD TO MODERAIOR button. This will send all of your information for inclusion to the public viewing area of TechKnow ${ }^{\mathrm{TM}}$. You will receive a confirmation message of its receipt within 48 hrs. *

*After your technology has been reviewed by the moderator, you will receive a second notification indicating its "approval" status. 


\section{Searching for Information}

Use the Search Feature.

\section{SEAREH}

1. Go to the GNET ${ }^{\mathrm{TM}}$ Technology Center and log into TechKnow ${ }^{\mathrm{TM}}$ with your UserID and Password or the guest account provided. If you do not have a TechKnow" user account, refer to the "Getting Started" section of this booklet.

2. Once inside TechKnow ${ }^{\mathrm{TM}}$, click on the green VIEW button located in the top-left corner of your screen. Eight buttons will appear at the top of your screen.

3. Click on the grey \&EARCT* button. Search fields and a search guide will appear at the bottom of your screen.

4. Enter your criteria into desired fields. Click on the SUBMIT QUERY button at the bottom when finished. An alphabet will appear in the bottom-left of your screen.

5. Click on either the desired letter or "Display All" option. A list of technology profiles will appear in the main window.

6. Scroll down through the list and click on the desired technology to view its entire profile.

* You may click on the searen button at any time to restart.

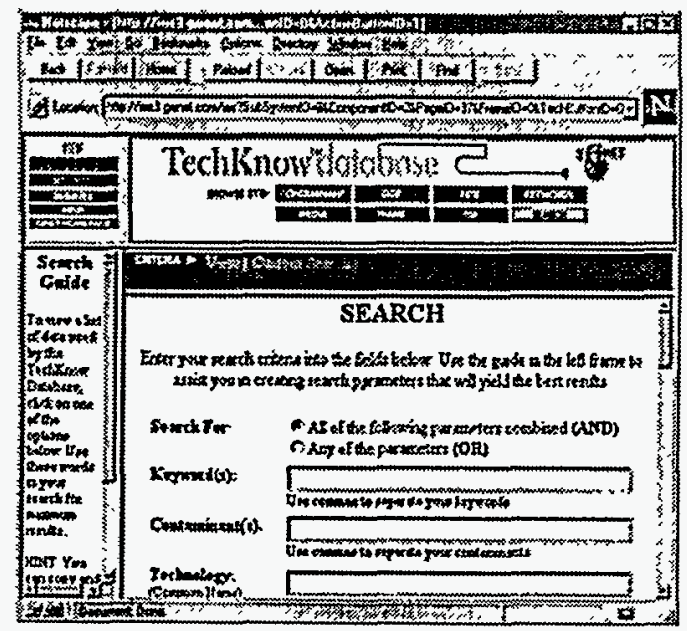




\section{Browse by Keyword. REYWORTS}

1. While inside the TechKnow" "View" mode, click on the purple KEYHORDS button. An alphabet will appear in the bottom-left corner of your screen.

2. You may either click on the desired letter, or the "Display All" (which will take a little longer to download). A list of keywords will appear in the bottom-left corner of your screen.

3. Scroll down the list and click on the desired keyword. A list of technologies which match your criteria will appear in the center of your screen (if no matches are found or you wish to try another keyword, just click on another from the list provided).

4. Click on the desired technology to view its full profile.
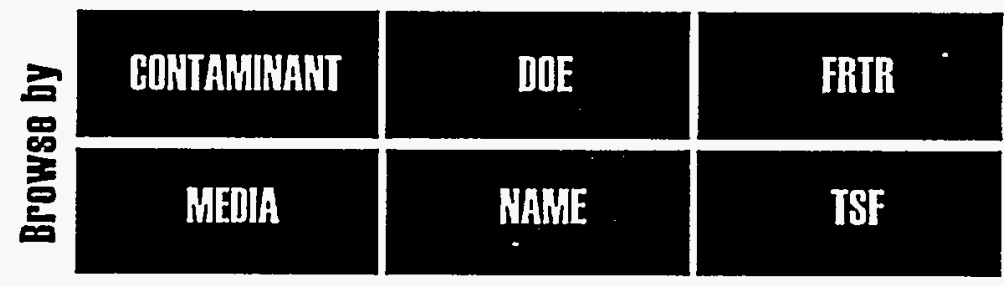

\section{Browse by Classification.}

1. While inside the TechKnow "View" mode, click on any of the following purple buttons: COHIAMIHAHT, MEDIA, DOE, HAME, FRIR, or TSF.* A list of classifications will appear in the bottom-left corner of your screen.

2. Click on the desired classification. A list of applicable technologies will appear in the main portion of your screen.

3. You may scroll through the list of technologies, or click on a letter from the alphabet menu located on the bottom-left corner of your screen.

4. Click on the desired technology to view its full profile.

* These classifications are further described on page 8 of this reference guide. 


\section{Updating Your Technology}

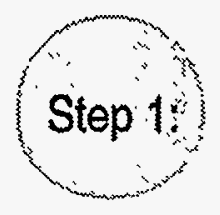

Locate your technology profile.

1. Enter GNET ${ }^{\mathrm{MN}}$ (http://www.gnet.org), click first on the "Technology Center," then click on the IECHKHOH' DATABASE button.

2. The TechKnow ${ }^{\text {TM }}$ Main Page will appear. Click on the EhIER IECHKHOW' button.

3. A window will appear asking you to $\log$ in. Type in your approved UserID and Password (remember this is case sensitive, it must exactly match) and hit enter.

4. Once inside TechKnow ${ }^{\mathrm{TM}}$, click on the green ADD/UPDAIE/ DELETE button, located in the top-left corner of your screen. Three buttons will appear at the top of your screen.

5. Click on the purple UPDAIE button. A group of buttons will appear in the bottom-left corner of your screen.

6. Click on the purple IECH LIST button. A listing of your technology profile with keywords will appear. If not, go to the "View" area (button at top-right of screen), locate the technology by name, and check the profile's editor field to see who is listed.

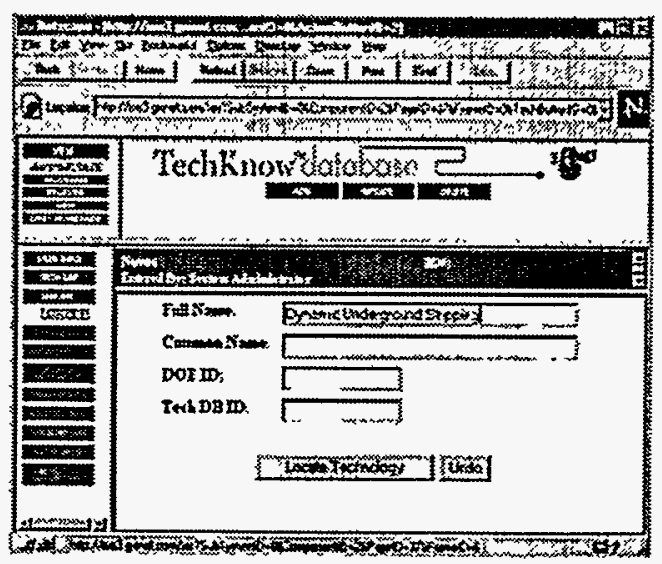

*If someone you are unfamiliar with is named as editor, you will need to notify GNET $^{\text {ix }}$ via e-mail to re-assign the profile to your account. 
Step 2: Update Your Technology Profile.

1. Once you have located your technology, click on it to view the entire profile. The buttons located on the bottom-left of your screen will become active.

2. Choosing from these buttons, click on the desired category*. The center of your screen will change and provide you with options on changing the specific fields.

3. Make changes as desired. At the end of each section you will be asked to save or clear your work.

* If you wish to add a keyword or category that is not included among the TechKnow menu options, send your request via e-mail to GNET ${ }^{\text {Th }}$ for consideration.

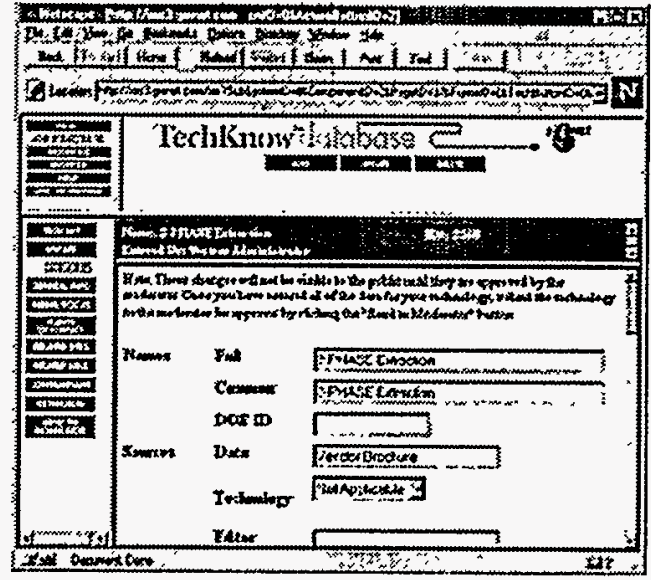

Step 3: Send Your Updated Technology Profile.

1. When you are finished updating your technology profile, review all changes for clerical errors and accuracy (e.g. URL addresses that work).

2. If you are satisfied that your updated profile is ready for public release, click the green SEHD TO MODERATOR button located at the bottom-left of your screen.

3. A "Send to Moderator" page will appear asking if you are sure you want to upload the updated profile to the public area of TechKnow ${ }^{\text {TM. }}$. Click the SuBMII IECHKOLOEY button to upload the profile.

4. You should receive an e-mail confirmation* within $48 \mathrm{hrs}$.

*After your update has been reviewed, you should receive a second notification stating if the updated profile was approved. 


\section{Understanding Keywords and Classifications}

\section{Keywords}

TechKnow ${ }^{\text {TM }}$ contains a keyword index of 756 words and phrases which are organized alphabetically. If a keyword is missing that you feel should be included in our index, you may request for its addition via e-mail.

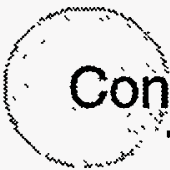

TechKnow ${ }^{\text {TM }}$ utilizes 16 of the most commonly used contaminant fields. You may access them through the "Contaminant" button while in the "View" mode.

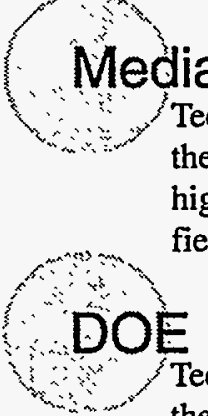

TechKnow ${ }^{\mathrm{TM}}$ identifies eight Focus and Crosscutting Areas in which the U.S. Department of Energy (DOE) targets their technology development programs. This system provides additional background on how potential technology projects can relate to DOE. Definitions for each Area maybe found in the "Help" section of TechKnow".

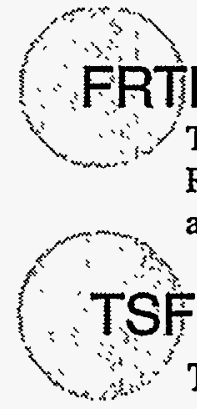

TechKnow ${ }^{T M}$ offers the White House's taxonomy for technology development from the Technology for a Sustainable Future (TSF) initiative. 


\section{Additional Tips}

\section{Printing Profiles and Lists}

TechKnow allows you to print out information from any portion of the system. When you select the "print" icon, your

Web browser will spawn a new browser page. Click the above print button within this new browser to print the screen. When finished, close this browser to get back to your original TechKnow ${ }^{\mathrm{TM}}$ screen.

\section{Chảnging Screen Size}

You may adjust the size of each frame within TechKnow ${ }^{\text {TM }}$. Simply move your mouse over the frames border until your cursor changes to "double arrows." Click and drag the frame across your screen to the desired position.

\section{Clicking on Related URLs}

TechKnow ${ }^{\mathrm{M}}$ includes hyperlinks to outside white papers, photographs, and other related Web sites. When you click on one of these links, your Web browser will spawn a new browser page containing the requested information. When finished, close this browser to get back to your original TechKnow ${ }^{\mathrm{TM}}$ screen.

\section{Using "Display All"}

TechKnow ${ }^{\mathrm{TM}}$ contains thousands of records in its system. Each time you click for information, the database is generating a custom page in response to your request. Therefore, choosing the "Display All" option may take some time to complete if you are using a modem. 


\section{Global Environment \&}

Technology Foundation (GETF)

7010 Little River Turnpike, Suite 300

Annandale, VA 22003

Phone (703) 750-6401

Fax (703) 750-6506

E-mail: gnet@getf.org

www.earthvision.net

www.gnet.org

www.iso14000.net

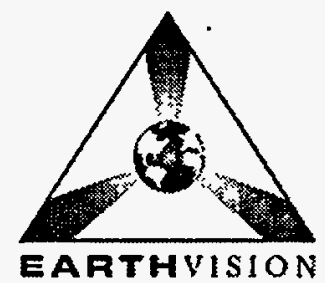

GNET ${ }^{\text {TM }}$ is a member of the EarthVision Network. 


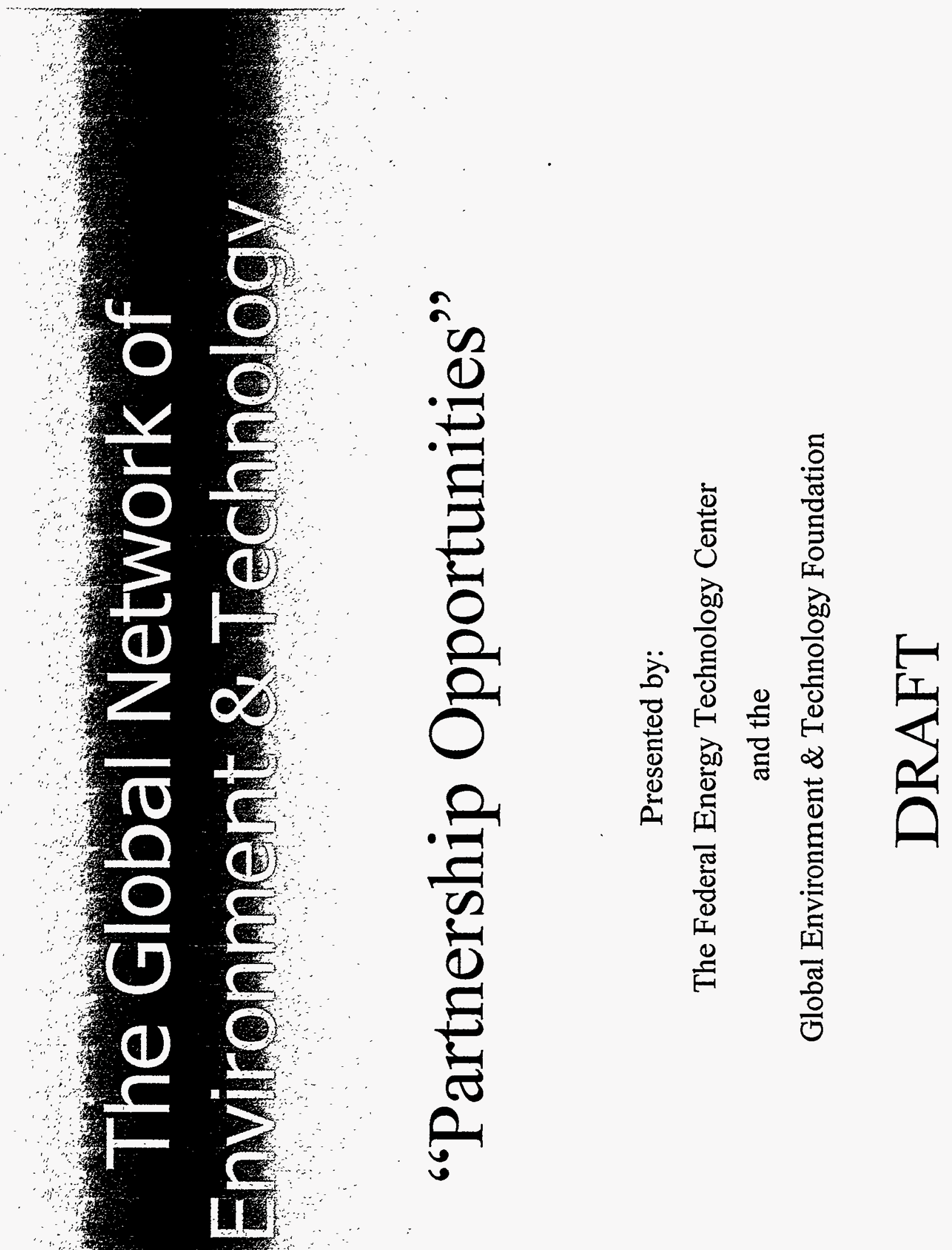




\section{About GNET \\ "Make the Connection"}

-\#1 Internet-based environmental technology

system (3 million hits annually)

- Global exposure (e.g., 160 countries now using)

-Turnkey Capability

-Flexible System Components 
- Cost effective tools and content

- Immediate affiliation with \#1 ET network

- Access to worldwide audience

- Proven approach for building networks to support national policy goals

- Accelerated "time to market" 


\section{The GNET System}

\section{"Worldwide Gateway"}

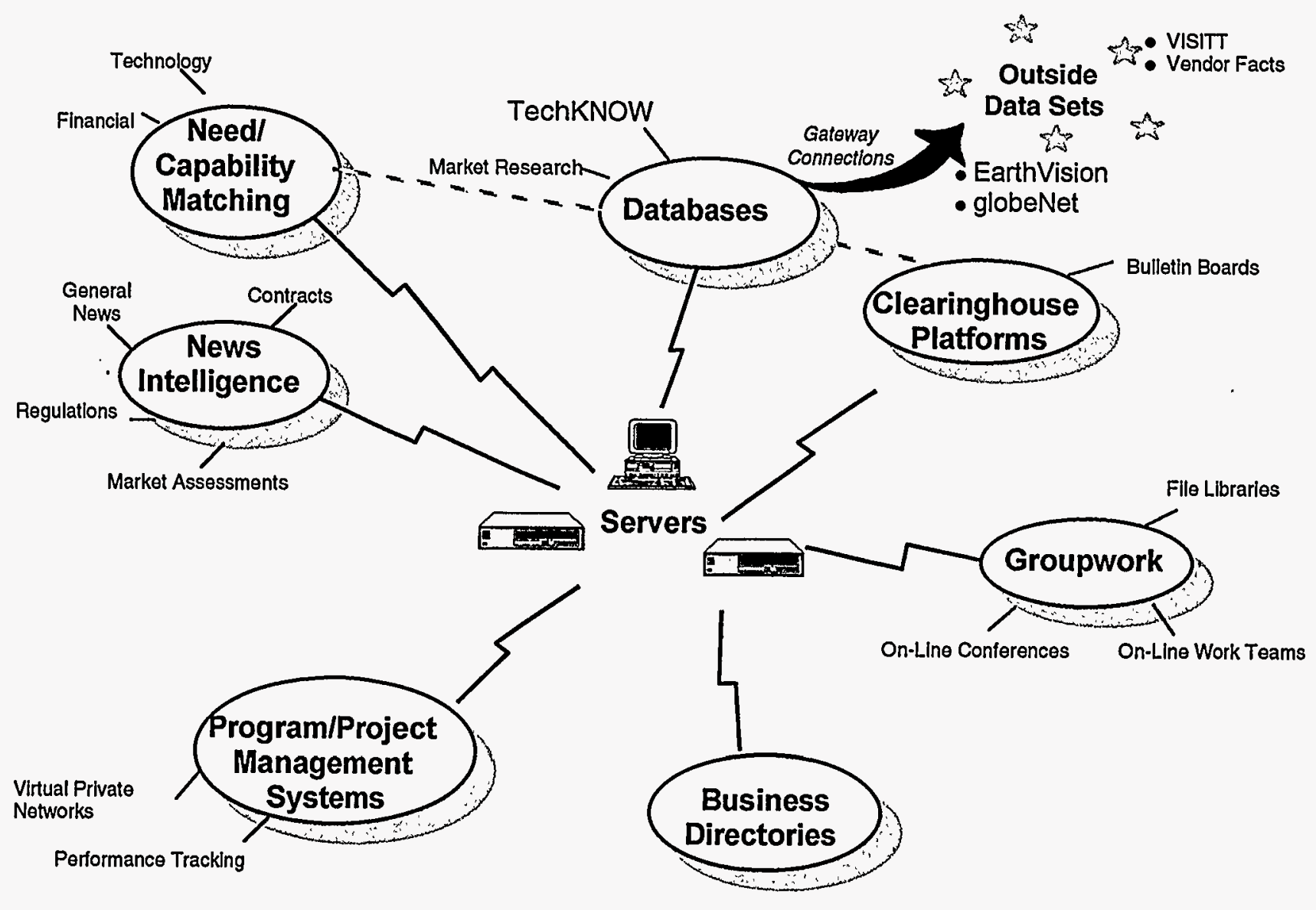




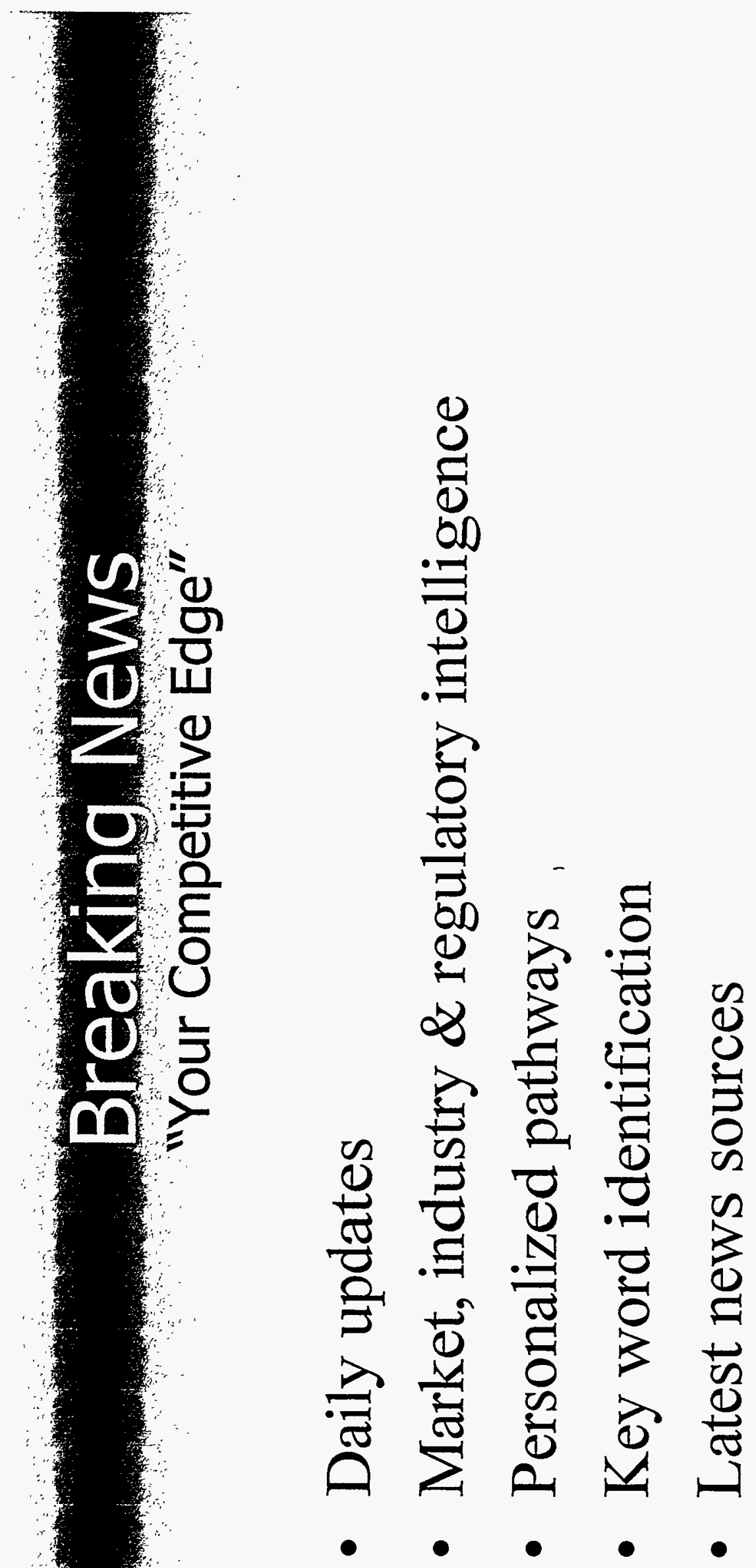




\section{A"TechKnow Partnership}

"Aggressive Technology Marketing"

- Worldwide exposure of technology

- Personalized subsets

- Targeted search protocols

- Real-time modifications \& information sharing

- Lower capital investment costs 


\section{Virtual Private Networks}

"Collaboration Made Easy \& Affordable"

- Secure virtual workspaces

- Effective collaboration tool

- Fully customizable to meet objectives (e.g., document sharing, file libraries, chats/meetings, news feeds)

- Many Agencies now using

- Lowers operational and travel expenses 


\section{Next Steps}

- Define your interests

- Develop partnership focus \& scope

- Implement partnership

- Ongoing outreach \& maintenance 